\title{
'Birds of a feather'? Assessing the prevalence of anti-immigration attitudes among the far right electorate
}

Article

Accepted Version

Stockemer, D., Halikiopoulou, D. and Vlandas, T. (2021) 'Birds of a feather'? Assessing the prevalence of anti-immigration attitudes among the far right electorate. Journal of Ethnic and Migration Studies, 47 (15). pp. 3409-3436. ISSN 1369-183X doi: https://doi.org/10.1080/1369183X.2020.1770063 Available at https://centaur.reading.ac.uk/90739/

It is advisable to refer to the publisher's version if you intend to cite from the work. See Guidance on citing.

To link to this article DOI: http://dx.doi.org/10.1080/1369183X.2020.1770063

Publisher: Taylor \& Francis

All outputs in CentAUR are protected by Intellectual Property Rights law, including copyright law. Copyright and IPR is retained by the creators or other copyright holders. Terms and conditions for use of this material are defined in the End User Agreement.

www.reading.ac.uk/centaur 
Central Archive at the University of Reading

Reading's research outputs online 


\title{
'Birds of a feather'? \\ Assessing the prevalence of anti-immigration attitudes among the far right electorate
}

\author{
Accepted in the Journal of Ethnic and Migration Studies, May 2020 \\ Daniel Stockemer (University of Ottawa) \\ Daphne Halikiopoulou (University of Reading) \\ Tim Vlandas (University of Oxford)
}

\begin{abstract}
This article focuses on the prevalence of anti-immigration attitudes among the far-right electorate. Drawing on the distinction between the predictive power of immigration concerns, and the question of how widespread these concerns are among the far-right voter pool, we proceed in two steps. First, we assess the extent to which anti-immigration attitudes are a necessary condition for voting far right; and second we examine whether far right voters with different levels of anti-immigration attitudes exhibit similar individual and attitudinal characteristics. Using data from the $8^{\text {th }}$ wave of the European Social Survey (ESS) we find that, surprisingly, anti-immigration attitudes are not a necessary condition for voting for the far right as approximately one third of far-right voters have no concerns over immigration. We further show that far-right voters with different levels of immigration concerns have different profiles when it comes to other predictors of the far right-vote including ideological affinity, attachment to the EU and government satisfaction. Our contribution is significant as we suggest that there are different routes to voting for the far right by groups with different grievances, including nonimmigration related.
\end{abstract}

Key words: far right, voters, anti-immigration attitudes, European Social Survey, Europe. 


\section{Introduction}

The increase in electoral support for parties on the far-right of the political spectrum has sparked growing academic interest on who votes for these parties and why (see e.g. Mudde and Rovira, Kaltwasser 2018). Complementing past work in the field of far-right voting behaviour, recent studies focus on the common features of the typical far-right voter, who is likely to be a lowly educated (Lucassen and Lubbers 2012; Stockemer et al 2018) male individual (Givens 2004; Immerzeel et al 2015) with poor prospects in the labour market (Halikiopoulou and Vlandas 2016; Swank and Betz 2003; Swank and Betz 2018). In terms of attitudinal characteristics, this individual is likely to be critical of immigration (e.g. Ivarsflaten 2008; Golder 2016; Rydgren 2008; Lucassen and Lubbers 2012; Halikiopoulou and Vlandas 2020). This makes sense theoretically, as far right parties have ownership of the immigration issue (e.g. Van de Brug and Fennema 2007; Van Spagne 2010). They attempt to capitalise on a broad range of voters' concerns- for example the erosion of cultural norms, competition in the labour market, public goods provision, crime and terrorism- by directly associating these concerns with immigration. In other words, we have theoretical reasons to expect anti-immigration attitudes to be a prominent feature of the typical far right voter.

A closer look at materials that carry out systematic reviews of empirical literature, however, suggests that evidence is more mixed than commonly assumed with regards to anti-immigration attitudes (e.g. Stockemer et. al 2018). Given that immigration is the signature theme of far-right parties, absence of agreement in the literature about the role of anti-immigration attitudes is particularly puzzling. This article argues that in order to evaluate the role anti-immigration attitudes play in far-right party support, it is important to distinguish between the predictive power of immigration concerns on the one hand, and the question of how widespread these 
concerns are among the far-right electorate on the other. Using data from the 8th wave of the European Social Survey (ESS), we confirm that anti-immigration attitudes are a strong driver of the far-right vote (e.g. Lucassen and Lubbers 2012; Lubbers and Güveli 2007; Rydgren 2008). More importantly, however, we illustrate that despite this predictive power anti-immigration attitudes are not a necessary condition for voting far right. A relatively large group of far-right voters (i.e. approximately one third) has neither cultural nor economic fears related to immigration. This group of supporters also differs from the typical far right voter profile in terms of education status, ideological affinity, attachment to the EU and level of satisfaction with the government.

In terms of theoretical and empirical significance, our findings are important as they suggest that there may be different routes to voting for the far right, and different voter groups might opt for these parties for different reasons and grievances, including non-immigration related. If we are right, then the mechanism linking voter preferences to far right parties is far more complex than the literature assumes.

This article proceeds as follows. First, we situate this study within the broader literature on farright party support. Second, we present our research questions and argument. Third, we discuss the data and methodological procedures adopted for this research. We then proceed to carry out our bivariate and multi-variate analyses and discuss our results. The article concludes by highlighting avenues for future research. 


\section{Explanations for the far-right vote}

Who votes for the far right and why? This question is the focus of a vast body of literature on far-right voting behaviour, which stresses the importance of different cultural, economic, social and institutional factors (Mudde and Rovira Kaltwasser 2018; Stockemer et al. 2018). Focusing on the emergence of a new post-material cleavage (Hooghe and Marks 2017) that divides voters along value-based lines, recent scholarship has emphasised the role of cultural drivers of far-right party support (Norris and Inglehart 2016). Much of this literature stresses the predictive power of cultural grievances at the individual level, suggesting that the most likely far-right voters are those concerned about globalisation and the large influx of outsiders. Those voters tend to reject foreigners on the premise of cultural norms (Golder 2016). Alternative perspectives emphasise the continued importance of material concerns, suggesting that austerity, economic deprivation and wealth inequalities continue to play an important role in driving far-right party support (Adler and Ansell 2019; Colantone 2018; Fetzer 2019; Engler and Weisstanner 2020; Halikiopoulou and Vlandas 2020).

Beyond the 'culture versus economy' debate, other perspectives adopt a social alienation angle. According to these approaches, far-right party support can also be the product of societal decline and status anxiety (Rydgren 2009; Gidron and Hall 2019; Gest 2016). This type of argument draws on Putnam's (2000) 'bowling alone' story, suggesting that the decline of social capital intensifies feelings of social alienation, drawing voters closer to anti-establishment parties. These approaches are complementary to explanations that focus on democratic alienation from an institutional perspective. Voters who mistrust democratic procedures (Hooghe et al 2011) and 
evaluate the quality of governance in their country poorly (Agerberg 2017) are more likely to support the far right.

In light of these debates, authors place varying emphasis on different predictors of far-right party support. Among others, these include low levels of education (Inglehart and Norris 2016; Andersen and Zimdars 2003; Harteveld et al. 2015; Kestilä-Kekkonen and Söderlund 2014), nationalist and/ or authoritarian attitudes (Lubbers and Coenders 2017), unemployment and/or limited access to the labour market (Halikiopoulou and Vlandas 2016; Swank and Betz 2003; Swank and Betz 2018), occupation (Lubbers and Scheepers 2002; Levi and Patriarca 2019), gender (Givens 2004; Immerzeel et al 2015), protest voting (Van der Brug and Fennema 2007), opinions about the quality of government (Halikiopoulou and Vasilopoulou 2018; Agerberg 2017) and extreme events such as an economic and/ or political crisis (Golder 2016).

\section{Anti-immigration attitudes}

What is striking from a first glance at this vast literature on the voters of the far right, however, is the identification of opposition to immigration as the variable with the greatest predictive power (e.g. Ivarsflaten 2008; Rydgren 2008; Golder 2016; Rooduijn et al 2017; Abbondanza and Bailo 2018; Halikiopoulou and Vlandas 2020). The emphasis on immigration makes sense from a supply side perspective, since this issue is at the heart of the far-right's message. Far right parties exploit the multi-faceted character of the immigration issue to target immigrants as threats to national security, employment, social security and the cohesion of European Judeo-Christian values (Williams 2010). The rapidly changing nature of the European far-right and its increased ability to permeate mainstream ground and set the political agenda (Halikiopoulou 2018; Mudde 2019) are partly reflected in the ways that these parties frame immigration. While the 'old', or 
extreme right, continues to justify the exclusion of immigrants primarily on the basis of ascriptive criteria such as race, blood and creed, the 'new' or populist radical right is increasingly putting forward civic justifications that draw on broader criteria of national belonging (Halikiopoulou et al 2013; Eger and Valdez 2018). Parties such as the FN, the Swiss Peoples' Party (SVP), the Alternative for Germany (AfD), the Austrian Freedom Party (FPÖ), the Lega, Fratelli d'Italia (FdI), and the UK Independence Party (UKIP), have (re) branded themselves and their programmatic agendas in an attempt to appeal as broadly as possible, including to voters with economic concerns (Ivaldi 2015; Levi and Patriarca 2019).

Supply and demand match if voters either respond to the far-right's brand-marking and scapegoating of immigrants, and develop anti-immigration attitudes or see their own migration critical attitudes confirmed by the far-right's rhetoric (Van Spagne 2010). As a result, they too might link multiple societal problems - ranging from unemployment to public insecurity - to the immigrant threat (Golder 2016) and consequently, vote for the far right. Individuals tend to fear immigrants for a variety of reasons. For example, as noted above, they might perceive them as a threat to the dominant value consensus and national way of life (Inglehart and Norris 2016). Concerns that the infiltration of alien values dilutes traditional social norms may fuel negative sentiments against immigrants, and drive voters to support parties that pledge strict immigration policies (Golder 2016).

Individuals may also perceive immigrants as competitors in the labour market (e.g. Mayda 2006; Dancygier and Donnelly 2013; Halikiopoulou and Vlandas 2020). This is especially the case for those social groups that are, or perceive that they are, vulnerable to competition (Polavieja 2016; Mayda 2006). The economic drivers of anti-immigration attitudes are distinct from, but may 
overlap with, the cultural drivers (Lubbers and Güveli 2007; Lucassen and Lubbers 2012; Hainmueller and Hopkins 2014; Halikiopoulou and Vlandas 2020). Recent studies also emphasise the importance of perceptions of crime levels (Rydgren 2008), terrorism risks (Hutchins and Halikiopoulou 2020; Ezzati 2020) and the presence of refugees (Altındağ and Kaushal 2020) as prime factors for shaping anti-immigration attitudes and the far-right vote.

This suggests that there are important reasons to expect immigration to be a key driver of far right party support. However, a closer look at materials that offer systematic literature reviews suggests that empirical evidence is more mixed, and immigration attitudes do not exhibit consistent influence in determining an individual's propensity to vote for a far-right party (Stockemer et al 2018; see also Van de Brug and Fennema 2007; Golder 2016). For example, from 470 immigration-related variables in the 36 studies covered in their sample, Stockemer et al (2018: 239) find only a 51 percent success rate (239 variables). Why is the empirical evidence more mixed than we might have otherwise expected?

\section{The prevalence of anti-immigration attitudes among the far-right electorate}

This article suggests that it is important to distinguish between the question of the predictive power of immigration concerns on the one hand, and the extent to which these concerns are prevalent among the entire far right electorate on the other (Halikiopoulou and Vlandas 2020). While a particular individual characteristic may have strong predictive power, not all voters of a particular political party exhibit this characteristic. To illustrate: using data from the ESS, we confirm the findings from previous literature (e.g. Golder 2016; Ivarsflaten 2008; Rydgren 2008; Inglehart and Norris 2016) that both cultural and economic concerns over immigration are strong 
predictors of far right party support (See Table A2 in Appendix). ${ }^{1}$ This suggests that voters who share sceptical attitudes towards immigration may be more likely to vote for far-right parties; it does not, however, automatically imply that every far-right voter shares these attitudes. On the contrary, there are many reasons to expect a diverse far-right party voting base, as with other party families.

In a world of catchall parties (Katz and Mair 1996), distinct party families no longer carve out the clear ideological positions of the 1950s and 1960s. Ideologies have become multidimensional (for example, individuals may be economically left leaning but conservative when it comes to values), and heuristics such as personality traits or even the physical attractiveness of politicians have become increasingly important (e.g. McAllister 2015; Rachat and Kenig 2018). This multidimensionality of issues applies to a range of party families. For example, while some voters clearly identify as left or right and liberal or conservative, and make their vote choice according to these ideological dispositions (Bobbio 1996, 92), this characteristic does not apply to all voters.

We might expect the same to apply to voters of the far right. The sheer electoral success of farright parties since 2014 underscores the possibility that these parties have extended their appeal well beyond their core, anti-immigrant voting base. Riding on a wave of success, many such

\footnotetext{
${ }^{1}$ To capture the influence of fears about immigration on the far-right vote, we use a dummy variable coded 1 if the respondent voted for the far right and 0 otherwise. To measure our independent variable, we include both economic and cultural fears, as well as an interaction between the two. Other controls include the following variables: education, age, gender, place of residence, religiosity, professional activity, self-placement on a left-right scale, attachment to the European Union, satisfaction with the government; participation in social/ civic activities; and perceived possibility to influence the political system (Norris 2005; Allen 2017) (see Table A1 in appendix for the operationalisation). Because our dependent variable is binary (coded 1 if respondents vote for far-right parties and 0 otherwise) we carry out logistic regression analysis (Long et al. 2006).
} 
parties, including the FN, the AfD and the Italian Lega, have doubled their vote share over the past decade, gaining 10, 15 and sometimes 20 to 30 percent of the popular vote. Alongside their leitmotif, the anti-immigration platform, these parties have increasingly adopted a populist platform with an anti-elitist message at its center. They challenge the political system, and all actors that represent it, as enemies of the popular will. In this sense they have become antiparties, seeking to capitalise on growing popular discontent, regardless of whether this discontent originates in the economic, cultural or social realm (Canovan 1999; Rooduijn 2016).

This suggests that instead of a uniform far-right voter profile (e.g. Arzheimer and Carter 2006; Halla et al. 2017), there may in fact exist different types of far-right voters. While some are responding to the anti-immigrant far right propaganda, others may be drawn by the populist, antielitist, anti-establishment and protest-orientated narrative of these parties (Akkerman et al 2014). In sum, the far-right party populist turn and the tremendous increase in electoral support that has accompanied it, render it plausible that different far-right party supporters vote for such parties for different reasons. This brings us to our first hypothesis:

\section{H(1): Anti-immigration attitudes are not a necessary condition for voting far right}

If our analysis confirms our theoretical expectations that voters may also choose far-right parties for reasons other than immigration, then a next step should be to examine these voters more closely. Debates within the inner circles of contemporary populist far-right parties such as the FN or the AfD reveal significant differences among party membership between the more ideologically driven and moderate members (Loew and Faas 2019). We might expect similar divides among the far right electorate. 
Voters with anti-immigration attitudes constitute the core far right voting base. Their opposition to immigration is ideological- or principled (Rydgren 2008; Halikiopoulou and Vlandas 2020). As such they are likely to also have strong nationalist (Lubbers and Coenders 2017) and antielitist (Akkerman et al 2014) attitudes expressed, for example, in their disapproval of the European Union and their domestic institutions. These voters also tend to be predominantly right-wing and may hold conservative social and religious values (e.g. Chandler and Tsai 2001) On the other hand, non-core voters are likely to be less ideological, supporting the far right for non-principled reasons. As such they may not necessarily hold explicitly strong nationalist positions. They may also differ from the core voters on a range of other individual and attitudinal characteristics including education, position in the labour market, religiosity and/or ideological affinity. From this, we derive our second hypothesis:

\section{H(2): Far-right supporters with anti-immigration attitudes are likely to have different individual and attitudinal characteristics from those supporters who are less sceptical of immigration}

\section{Research Design}

We test our two hypotheses using data from the ESS (2018). ${ }^{2}$ We categorize 'far right' parties according to the definitions provided by Lucassen and Lubbers (2012, as well as Halikiopoulou and Vlandas (2020), which yields a list of 21 parties in 16 countries (see Table A3 in the

\footnotetext{
${ }^{2}$ Asking questions about attitudinal, political, and demographic factors, the ESS allows for individual level analyses across cases and across time. We restrict our analysis to the 8th wave, of the ESS (2016) ( $\mathrm{N}=31000)$. Using the ESS also follows a long tradition of studies in the fields of far right parties and voting behaviour (e.g. Ivarsflaten 2008; Lucassen and Lubbers 2012; Rydgren 2008, Oesch 2008).
} 
Appendix). ${ }^{3}$ In order to proceed in our analysis, it is important to first specify what it means to hold anti-immigration attitudes. This specification is the more important the more voters choose the middle value between negative and positive sentiments toward immigrants. In methodological terms, this entails caution when assigning individuals to categories, which suggest they hold anti-immigration attitudes. The problem is amplified by the fact that we lack a clear-cut theoretical definition, which would allow us to determine the cut-off point between those who hold and those who do not hold anti-immigration attitudes. Nevertheless, we can probably agree that individuals who are in the middle (5 on the $0-10$ scale) are neither pro- nor anti-immigrant and hold neutral attitudes on whether immigrants enrich the economic and cultural life of a country.

Using the cut-off point of 5 , we assign voters to one of the four categories: (1) voters with economic and cultural fears related to immigration; (2) voters with predominantly economic fears; (3) voters with predominantly cultural fears; and (4) voters with neither cultural nor economic fears ${ }^{4}$. To do so, we create a binary distinction between the absence and the presence of economic and cultural fears. In an additional coding, we proceed by categorising respondents on the neutral scale (5) as holding anti-immigrant attitudes. This categorization is even more conservative as we only code individuals who rate both immigration proxies at a value of 6 or higher as having neither economic nor cultural fears. The aim of this additional coding is to

\footnotetext{
${ }^{3}$ The version of the ESS (2018) data we use includes 23 countries. We excluded Russia and Israel because they are not in Europe. We also excluded Ireland, Iceland, Luxembourg, and Spain because there was no far right party at the time of data collection in 2016 that was sufficiently strong to be listed as a vote choice in the ESS.

${ }^{4}$ We test whether the assumption of irrelevant alternatives (IIA) hold: a Suest- Hausmann test of IIA confirms that this is not a problem.
} 
identify whether there is still a sizable percentage of far-right voters without any kind of antiimmigration attitudes or fears, even if we exclude the middle category.

To provide a first overview of where voters stand concerning anti-immigrant attitudes, we combine the two 0 to 10 scales on cultural and economic fears to one 0 to 20 scale, and show both the raw numbers and the percentage of far-right voters within each category. In a second and third step, we present the distribution of different types of far-right voters, with a benchmark of 5 and 6 for having these fears, respectively. Fourth, we display some histograms of all independent variables across the four categories of far-right voters. These histograms give us some indication on whether far right voters with or without immigration fears display different characteristics. Fifth, we run a multiple regression model. The dependent variable distinguishes four types of far-right voters: (1) voters with neither economic nor cultural fears related to immigration, (2) voters with economic fears related to immigration, (3) voters with cultural fears related to immigration, (4) voters with economic and cultural fears related to immigration. The reference category refers to voters with neither economic nor cultural fears related to immigration. Because our dependent variable is categorical, with no hierarchy in the categories, we carry out multinomial logistic regression analysis (Long et al. 2006). Our controls are the same as before. We also add country fixed effects to control for all country specific variation, as well as clustered standard errors by country. Since this maximum likelihood estimation does not allow us to directly interpret the coefficients, we also present predicted probability plots of all our independent variables. These predicted probabilities display the graphical representation of the possible varying effect of any of the independent variables on our four categories of voters. 


\section{Results}

Our results support $\mathrm{H}(1)$. Specifically we find that not everyone who votes for the far right necessarily fears or rejects immigrants (Tables 1 and 2). On the contrary, a relatively large group of far-right voters is either neutral in terms of their immigration stance, or pro-immigrant. For example, Table 1, which combines the cultural and economic immigration sentiment proxy on a 0 to 20 scale illustrates that the majority of voters is below the threshold of 10 entailing they are sceptical of immigrants to varying degrees. However, we also see that roughly one-third (36 percent of far-right voters) are above the threshold of 10 , entailing that there is a sizable proportion of voters who do not hold anti-immigration attitudes. If we look at Table 2 and take the 5-point cut-off, more than 30 percent of far right-voters have neither economic nor cultural fears related to immigration. This is a remarkable number given that these parties' dominant focus is on immigration.

Table 3 further illustrates that we can distinguish between two large groups of far-right voters if we take their positions on immigration as their defining feature. Rather unsurprisingly, the largest group of far-right voters, comprising roughly 42 percent of respondents, are voters who think that immigrants pose both a cultural and economic threat. However, the second largest group of far-right voters are voters who have neither cultural nor economic concerns over immigration. This group makes up roughly 32 percent of self-declared far-right voters. The final two groups, voters with predominantly economic or predominantly cultural fears only make a relatively small percentage of the total of self-declared far-right voters. The former group consists of 16 percent of the total of radical right supporters and the latter of roughly 11 percent. Even if we include the middle category of 5 as having immigration related fears, there are still 15 percent of far-right voters in the category of no economic and no cultural fears (see Table 3). 


\section{<Tables 1, 2 and 3 about here >}

This implies that the far-right has reached out beyond its core. Not everyone who votes for the far right does so because they reject immigrants. The fact that we have a heterogeneous pool of voters when it comes to support for the far-right's leitmotiv of immigration, supports the plausibility of different types of support bases; that is, these different groups of voters could also be distinct when it comes to other characteristics of the far-right vote. In particular, it is possible that the two largest blocks of far-right voters, i.e. voters with economic and cultural concerns over immigration, and voters with neither concern, differ concerning other characteristics, such as attachment to the EU or degree of religiosity. A series of histograms documents differences between far-right voters, in particular between those voters with economic and cultural concerns related to immigration, and those voters where these concerns are absent (see Appendix).

A more formal analysis presented in Table 5 and Figures 1 to 11 largely confirms this initial descriptive picture. In support of $\mathrm{H}(2)$, we find that there are key differences between our two main groups of voters - voters with economic and cultural fears, and voters who do not express these fears - concerning the influence of four factors: (1) left-right placement, (2) attachment to the European Union and (3) satisfaction with the government, (4) the feeling on whether they can influence the political system. ${ }^{5}$ For the two small groups of voters, i.e. voters with either cultural

\footnotetext{
${ }^{5}$ For some of the statistically significant variables (e.g. satisfaction with the EU), the confidence intervals overlap between our main categories (i.e. voters with immigration fears and voters without immigration fears). However, this is unavoidable if for one type of voter the likelihood of voting for the far-right increases, while it decreases for the other type.
} 
or economic fears, the different effects of the 11 variables are minor and as such, we do not discuss differences in detail.

Our results confirm that we may distinguish between two types of far-right voters: ideologues who constitute the core, principled, anti-immigrant far-right voting base, and peripheral moderates who are not particularly concerned with immigration. Ideologues have both economic and cultural concerns over immigration; they are also more right-wing than voters without these fears (see Figure 1 and 7). This finding is in line with the literature on anti-immigration sentiment, which argues that right-leaning individuals are more likely to hold positions critical of immigration (see Chandler and Tsai 2001; Rustenbach 2010). In addition, their likelihood to vote for the far right further increases with their dissatisfaction with the national government and the EU (see Figures 8 and 9). They are also more likely to vote for the far right the less they believe they are able to influence the political system decreases (see Figure 11).

In contrast, peripheral moderates are those with less explicit anti-immigration sentiments. Our analysis yields a range of particularly interesting results with regards to this group. Specifically, these voters are distinct from the ideologues in that their likelihood of voting for the far right increases with their satisfaction with the government and the EU. Voters in this group are not necessarily right-wing, but they have an increased probability to vote far right if they think that they can influence the political system. It is likely that these voters see the-far right as an alternative means of political engagement, in the absence of the possibility of influencing the system through mainstream parties. 
With regards to religiosity, it is theoretically possible that far right-voters with anti-immigration sentiments are more religious than those without these fears. Religion could induce negative attitudes towards immigrants (Bloom at al 2015) considering that far-right parties often attempt to mobilise immigration concerns on religious grounds, for example by presenting themselves as defenders of Christian values against Islam (e.g. Froio 2018). In doing so they have partly displaced conservative and Christian democratic parties as the main protectors of Christian identity. In addition, the combination of religious purity coupled with the anti-immigration sentiment might resonate well with religious fundamentalists or individuals with absolutist religious beliefs (see Bloom et al 2015). However our empirical analysis suggests that the moderates are not necessarily less likely than the ideologues to hold religious values.

In order to reassure both the reader and ourselves regarding the validity of our findings we conduct some alternative specifications with our data. For example, if we exclude the two governing parties at the time of the survey - the Hungarian Fidesz Party and the Polish Pis Party - the findings in Figures 1 to 11 do not change.

$<$ Table 5 about here>

<Figures 1 to 11 about here>

\section{Conclusion}

This article has focused on the diverse voting pool of far-right parties. We commence from an initial observation that the empirical literature on far-right voting tends to produce inconclusive 
results that often do not match the theoretical expectations that there is one type of far-right voter, especially concerning the far right's signature theme of immigration. This suggests that insufficient attention has been paid to the fact that the far right voting base could consist of groups with different characteristics and preferences. In order to assess this claim empirically we have tested the extent to which immigration attitudes are a necessary condition for far-right voting and examined the individual and attitudinal characteristics of different far right voter groups. Our results from both bivariate and multivariate analyses, using data from the $8^{\text {th }}$ wave of the ESS illustrate that the pool of far-right supporters is more diverse and heterogeneous than we might expect, confirming that far-right voters are not drawn from one demographic cohort. Instead, the far-right voter pool is diverse as multiple can paths lead to far-right party support.

Our contribution is significant as the identification of different routes to voting for the far right by groups with different grievances, including non- immigration related, challenges the conventional wisdom that focuses almost exclusively on immigration as the key driver of farright party support. If one third of far-right voters are individuals with neither cultural nor economic concerns over immigration, then the mechanisms linking voter preferences to far-right parties is far more complex than the literature assumes. This is especially pertinent at a time when the far right has tripled its vote share in many countries. To extend their support to such a degree, far-right parties must mobilise beyond their secure, or traditional, voting base and attract diverse population groups. Why and how they do this, especially beyond their immigration comfort zone, is pivotal for understanding far right party support.

Our study has offered a first step in understanding different types of far-right voters. Our overall finding, i.e. that not everyone votes for the far right because of immigration-related fears, is in 
itself important. Limitations in our design, however, allow room for further examination. First, data availability has restricted the scope of our research. As the ESS $8^{\text {th }}$ wave was conducted in 2016, and does not cover all European countries, we were not able to include some far-right populist parties such- for example UKIP- or capture voting trends during the latest populist wave in 2017 in our analysis. Second, we mainly point to correlations rather than causal connections in our research design. Third, the static nature of our study entails that we only measure differences in types of far-right voters at one point in time. This design does not allow us to follow individual trajectories of far-right party support. For example, it is possible that peripheral voters initially vote for the far right for reasons other than immigration, but in the long run become socialised into these parties and endorse their ideological positions. This would entail a transition from peripheral to principled voting. Or it may be the opposite: their lack of strong ideological positions entails they are occasional far-right voters, more likely to abandon the far right at the next election.

Longitudinal, panel or experimental studies, could further examine these possibilities. Specifically, future research should delve more closely into mechanisms that link each type of voter to the far right. The identification of the specific circumstances under which different voters may be drawn to the far right will significantly benefit the research community. 


\section{References}

Abbondanza, G. \& Bailo, F. (2018). The electoral payoff of immigration flows for antiimmigration parties: The case of Italy's Lega Nord. European Political Science, 17(3), 378-403.

Adler, D. and Ansell, B. (2020). "Housing and populism”, West European Politics, 43(2): 344365.

Agerberg, M. (2017), Failed expectations: Quality of government and support for populist parties in Europe. European Journal of Political Research, 56(3): 578-600.

Akkerman, A., Mudde, C., \& Zaslove, A. (2014). How Populist Are the People? Measuring Populist Attitudes in Voters. Comparative Political Studies, 47(9), 1324-1353.

https://doi.org/10.1177/0010414013512600

Allen, T. J. (2017). Exit to the right? Comparing far right voters and abstainers in Western Europe. Electoral Studies, 50(1): 103-115.

Altındağ, O., Kaushal, N. (2020). Do refugees impact voting behavior in the host country? Evidence from Syrian refugee inflows to Turkey. Public Choice. https://doi.org/10.1007/s11127019-00768-3

Andersen, R. \& Zimdars, A. (2003), 'Class, Education and Extreme Party Support in Germany, 1991-98', German Politics, 12(2): 1-23. 
Arzheimer, K. (2009). "Contextual Factors and the Extreme Right Vote in Western Europe, 1980- 2002.” American Journal of Political Science 53(2): 259-275.

Arzheimer, K., \& Carter, E. (2006). Political opportunity structures and right-wing extremist party success. European Journal of Political Research, 45(3): 419-443.

Bloom, P. B. N., Arikan, G., \& Courtemanche, M. (2015). Religious social identity, religious belief, and anti-immigration sentiment. American Political Science Review, 109(2), 203-221.

Bobbio, N. (1996). Left and Right: The Significance of a Political Distinction. Cambridge: Polity.

Chandler, C. R., \& Tsai, Y. M. (2001). Social factors influencing immigration attitudes: an analysis of data from the General Social Survey. The Social Science Journal, 38(2), 177-188.

Colantone, I., S. P. (2018). "The trade origins of economic nationalism: Import competition and voting behavior in Western Europe", American Journal of Political Science, 62(4): 936-953.

Canovan, M. (1999). Trust the people! Populism and the two faces of democracy. Political Studies, 47(1), 2-16.

Dancygier, R. M. \& Donnelly M. J. (2013). "Sectoral Economies, Economic Contexts, and Attitudes toward Immigration." The Journal of Politics, 75(1): 17-35 
Engler, S. and Weisstanner, D. (2020). "The threat of social decline: income inequality and radical right support", Journal of European Public Policy,

DOI:10.1080/13501763.2020.1733636

Eatwell, R. (2016). 21 Ten theories of the extreme right. The Populist Radical Right: A Reader, 404.

Eger, M. A., \& Valdez, S. (2018). From radical right to neo-nationalist. European Political Science. Online First. https://doi.org/ 10.1057/s41304-018-0160-0

Evans, J. A. (2005). The dynamics of social change in radical right-wing populist party support. Comparative European Politics, 3(1): 76-101.

Ezzati, R. T. (2020) Value-talk after terrorism: articulating a united 'we' and a divided 'us', Journal of Ethnic and Migration Studies, DOI: 10.1080/1369183X.2020.1752637

Fennema, M. (1997), "Some Conceptual Issues and Problems in the Comparison of AntiImmigrant Parties in Western Europe", Party Politics 3(4), 473-492.

Fetzer, T. (2019). “Did austerity cause Brexit?” American Economic Review, 109:11, 3849_ 3886.

Ford R \& Goodwin M (2014) Revolt on the Right. Abindgdon: Routledge. 
Froio, C. (2018). Race, Religion, or Culture? Framing Islam between Racism and Neo-Racism in the Online Network of the French Far Right. Perspectives on Politics, 16(3), 696-709. doi:10.1017/S1537592718001573

Gest, J. (2016). The New Minority. Oxford: Oxford University Press.

Gidron, N. and Hall, P. (2019). Populism as a Problem of Social Integration. Comparative Political Studies, https://doi.org/10.1177/0010414019879947

Givens, T.E. (2004), ‘The Radical Right Gender Gap', Comparative Political Studies, 37(1): 3054.

Golder, M. (2003). “Explaining Variation In The Success Of Extreme Right Parties In Western Europe.” Comparative Political Studies, 36(4): 432-466.

Golder, M. (2016). “Far right parties in Europe.” Annual Review of Political Science 19(1): 477497.

Hainsworth, P. (2008). The extreme right in Western Europe. Abingdon: Routledge.

Halikiopoulou, D. ( 2018) A Right-wing Populist Momentum? A Review of 2017 Elections Across Europe. JCMS: Journal of Common Market Studies, 56: 63-73. https://doi.org/10.1111/jcms.12769. 
Halikiopoulou, D. \& Vasilopoulou, S. (2018). Breaching the social contract: crises of democratic representation and patterns of extreme right party support, Government and Opposition, 53(1): 26-50.

Halikiopoulou, D. and Vlandas, T. (2020). "When economic and cultural interests align: the antiimmigration voter coalitions driving far right party success in Europe”. European Political Science Review. ISSN 1755-7739 (In Press)

Halla, M., Wagner, A. F., \& Zweimüller, J. (2017). Immigration and voting for the far right. Journal of the European Economic Association, 15(6): 1341-1385.

Hainmueller, J., \& Hopkins, D. J. (2014). Public attitudes toward immigration. Annual Review of Political Science, 17, 225-249.

Harteveld, E., Van Der Brug, W., Dahlberg, S. \& Kokkonen, A. (2015), 'The Gender Gap in Populist Radical-Right Voting: Examining the Demand Side in Western and Eastern Europe', Patterns of Prejudice, 49(1-2): 103-34.

Hooghe M., Marien, S. and Pauwels, T. (2011). "Where Do Distrusting Voters Turn if There is No Viable Exit or Voice Option? The Impact of Political Trust on Electoral Behaviour in the Belgian Regional Elections of June 2009”. Government and Opposition, 46:2, 245-273.

Hooghe, L. and Marks G. (2018). “Cleavage theory meets Europe’s crises: Lipset, Rokkan, and the transnational cleavage." Journal of European Public Policy, 25(1): 109-135. 
Hutchins, RD, Halikiopoulou, D. (2020) Enemies of liberty? Nationalism, immigration, and the framing of terrorism in the agenda of the Front National. Nations and Nationalism. 26: 67-

\section{4. https://doi.org/10.1111/nana.12555}

Immerzeel, T., Coffé, H. \&van der Lippe, T. (2015), 'Explaining the Gender Gap in Radical Right Voting: A Cross-national Investigation in 12 Western European Countries', Comparative European Politics, 13(2): 263-86.

Inglehart, R. \& Norris P. (2016). “Trump, Brexit, and the Rise of Populism: Economic HaveNots and Cultural Backlash”, Harvard Kennedy School Faculty Research Working Paper Series [accessed on 26/01/17]

Ivaldi, G. (2015). Towards the median economic crisis voter? The new leftist economic agenda of the Front National in France. French Politics 13:346-369.

Ivarsflaten, E. (2008). "What unites right-wing populists in Western Europe? Re- examining grievance mobilization models in seven successful cases.” Comparative Political Studies, 41(1): $3-23$.

Katz, R. S., \& Mair, P. (1996). Cadre, catch-all or cartel? A rejoinder. Party Politics, 2(4), 525534.

Kestilä-Kekkonen, E. \& Söderlund, P. (2014), 'Party, Leader or Candidate? Dissecting 
the Right-wing Populist Vote in Finland', European Political Science Review, 6(4): 641-62.

Kinder, D. R., \& Kalmoe, N. P. (2017). Neither liberal nor conservative: Ideological innocence in the American public. University of Chicago Press

King G, Rosen O, Tanner, M \& Wagner A (2008) Ordinary Economic Voting Behavior in the Extraordinary Election of Adolf Hitler, The Journal Of Economic History, 68(4): 951-996.

Lipset SM (1960) Political Man: The Social Bases of Politics. New York: Doubleday

Long, S. J., Long, J. S., \& Freese, J. (2006). Regression models for categorical dependent variables using Stata. College Station: Stata press.

Loew, N., \& Faas, T. (2019). Between thin-and host-ideologies: How populist attitudes interact with policy preferences in shaping voting behaviour. Representation, 55(4), 493-511.

Lubbers, M. and Coenders M. (2017). "Nationalistic attitudes and voting for the radical right in Europe.” European Union Politics, 18(1): 98 - 118

Lubbers, M. \& Scheepers P. (2002). "French Front National voting: a micro and macro perspective". Ethnic and Racial Studies, 25(1): 120-149

Lubbers, M/ \& Güveli A. (2007). "Voting LPF: Stratification and the varying importance of attitudes”. Journal of Elections, Public Opinion and Parties, 17(1): 21-48. 
Lucassen, G. \& Lubbers M. (2012). "Who Fears What? Explaining Far-Right-Wing Preference in Europe by Distinguishing Perceived Cultural and Economic Ethnic Threats." Comparative Political Studies, 45(5): 547-574.

Mayda, A. M. (2006). "Who is against immigration? A cross-country investigation of individual attitudes toward immigrants.” The Review of Economics and Statistics, 88(3): 510-530

Mayer, N (2013). From Jean-Marie to Marine Le Pen: Electoral Change on the Far Right. Parliamentary Affairs 66(1): 160-178

Mellon, J \& Evans, G. (2015) Class, Electoral Geography and the Future of UKIP: Labour's Secret Weapon? Parliamentary Affairs, 69(2): 492-498.

McAllister, I. (2015). The personalization of politics in Australia. Party Politics, 21(3), 337-345.

Mudde, C. (2007). Populist radical right parties in Europe. Cambridge: Cambridge University Press.

Mudde, C. (2010). The populist radical right: A pathological normalcy. West European Politics, 33(6), 1167-1186.

Mudde, C. 2012. "The relationship between immigration and nativism in Europe and north America", Washington DC: Migration Policy Institute [accessed on 24/11/17] 
Mudde, C. (2019). The Far Right Today. Cambridge: Polity Press

Mudde, C. \& Rovira Kaltwasser C. (2018). "Studying Populism in Comparative Perspective: Reflections on the Contemporary and Future Research Agenda", Comparative Political Studies 51(13): 1667-1693

Norris, P. (2005). Radical right: Voters and parties in the electoral market. Cambridge: Cambridge University Press.

Oesch, D.. (2008). 'Explaining Workers' Support for Right-Wing Populist Parties in Western Europe: Evidence from Austria, Belgium, France, Norway, and Switzerland.” International Political Science Review, 29(3): 349-373.

Putnam, R. D. (2000). Bowling alone: The collapse and revival of American community. New York: Simon and schuster.

Rahat, G., \& Kenig, O. (2018). From Party Politics to Personalized Politics?: Party Change and Political Personalization in Democracies. Oxford: Oxford University Press.

Rooduijn, M. (2016). Simply studying populism is no longer enough. Nature News, 540(7633), 317. 
Rooduijn, M., Burgoon B., van Elsas E. J. \& van de Werfhorst H J. (2017). "Radical distinction: Support for radical left and radical right parties in Europe", European Union Politics, 18(4): 536 -559 .

Rustenbach, E. (2010). Sources of negative attitudes toward immigrants in Europe: A multi-level analysis. International migration review, 44(1), 53-77.

Rydgren, J. (2008). "Immigration sceptics, xenophobes or racists? Radical right-wing voting in six West European countries". European Journal of Political Research, 47(6): 737-765.

Rydgren, J. (2009). "Social isolation? social capital and radical right-wing voting in Western Europe”. Journal of Civil Society, 5:2, 129-150.

Sniderman, L. M., Hagendoorn L. \& Prior M. (2004). "Predisposing factors and situational triggers: Exclusionary reactions to immigrant minorities". American Political Science Review, 98(1): 35-49.

Stockemer, D. \& Amengay, A. (2015) The voters of the FN under Jean-Marie Le Pen and Marine Le Pen: Continuity or change? French politics French Politics 13, 370-390.

Stockemer, D. (2016). "Structural Data on Immigration or Immigration Perceptions? What Accounts for the Electoral Success of the Radical Right in Europe?" JCMS: Journal of Common Market Studies, 54(4): 999-1016. 
Stockemer, D. Lentz T. \& Mayer D. (2018) “Individual Predictors of the Radical Right-Wing Vote in Europe: A Meta- Analysis of Articles in Peer-Reviewed Journals (1995-2016)” Government and Opposition, Vol. 53(3): 569-593.

Swank, D. \& Betz, H.G. (2003). "Globalization, the Welfare State and Right-Wing Populism in Western Europe”. Socio-Economic Review, 1(1): 215-45.

Swank, D. and Betz, H. G. (2018). “Globalization, Institutions of Social Solidarity, and Radical Right-Wing Populism in Western Europe", Paper prepared for presentation at the 2018 Annual Meetings of the American Political Science Association, August 30 - September 2, Boston, MA.

Van der Brug, W., Fennema M. \& Tillie J. (2005). "Why Some Anti- Immigrant Parties Fail and Others Succeed: A Two-Step Model of Aggregate Electoral Support.” Comparative Political Studies, 38(5): 537-573,

Van der Brug, W. \& Fennema, M. (2007). "What causes people to vote for a radical-right party? A review of recent work." International Journal of Public Opinion Research 19(4): 474-487.

Van Spanje, J. (2010). Contagious parties: Anti-immigration parties and their impact on other parties’ immigration stances in contemporary Western Europe. Party Politics, 16(5): 563-586.

Vasilopoulou, S. \& Halikiopoulou D. (2015). The Golden Dawn's nationalist Solution: Explaining the Rise of the Far Right in Greece, New York: Palgrave. 
Williams, M. H. (2010). Can leopards change their spots? Between xenophobia and trans-ethnic populism among West European far right parties. Nationalism and Ethnic Politics, 16(1), 111134. 


\section{Figures and Tables}

Table 1: Distribution of far-right voters by degree to which they fear immigration, scale 0-20

\begin{tabular}{|l|l|l|l|l|}
\hline & Immigration fears & Far right voters & Percent & Cum. Percent \\
\hline Very strong fears & 0 & 253 & 10.23 & 10.23 \\
\hline & 1 & 60 & 2.43 & 12.65 \\
\hline & 2 & 125 & 5.05 & 17.70 \\
\hline & 3 & 95 & 3.84 & 21.54 \\
\hline & 4 & 145 & 5.86 & 27.41 \\
\hline & 5 & 129 & 5.21 & 32.62 \\
\hline & 6 & 178 & 7.19 & 39.81 \\
\hline & 7 & 183 & 7.40 & 47.21 \\
\hline & 8 & 220 & 8.89 & 56.10 \\
\hline & 9 & 166 & 6.71 & 62.81 \\
\hline & 10 & 270 & 10.91 & 73.73 \\
\hline & 11 & 153 & 6.18 & 79.91 \\
\hline & 12 & 147 & 5.94 & 85.85 \\
\hline & 13 & 125 & 5.05 & 90.91 \\
\hline & 14 & 73 & 2.95 & 93.86 \\
\hline & 15 & 61 & 2.47 & 96.32 \\
\hline & 16 & 43 & 1.74 & 98.04 \\
\hline & 17 & 23 & .93 & 98.99 \\
\hline & 18 & 15 & .61 & 99.60 \\
\hline & 19 & 5 & .2 & 99.80 \\
\hline & 20 & 5 & .2 & 100 \\
\hline
\end{tabular}


Table 2: Different types of far right voters (benchmark at 5 for both dimensions)

\begin{tabular}{|l|l|l|}
\hline & Raw number & Percent \\
\hline Economic and cultural fears & 1081 & $41.66 \%$ \\
\hline Economic fears & 409 & $15.76 \%$ \\
\hline Cultural fears & 285 & $10.98 \%$ \\
\hline $\begin{array}{l}\text { Neither cultural nor economic } \\
\text { fears }\end{array}$ & 820 & $31.59 \%$ \\
\hline Total & 2595 & 100 \\
\hline
\end{tabular}

Table 3: Different types of far right voters (benchmark at 6 for both dimensions)

\begin{tabular}{|l|l|l|}
\hline & Raw number & Percent \\
\hline Economic and cultural fears & 1621 & $62.47 \%$ \\
\hline Economic fears & 350 & $13.49 \%$ \\
\hline Cultural fears & 222 & $8.55 \%$ \\
\hline $\begin{array}{l}\text { Neither cultural nor economic } \\
\text { fears }\end{array}$ & 402 & $15.49 \%$ \\
\hline Total & 2595 & 100 \\
\hline
\end{tabular}


Table 4: Multinomial logistic regression of far-right voters with different immigration concerns

\begin{tabular}{|c|c|c|c|}
\hline Model & $\mathbf{I}$ & II & III \\
\hline Education & $\begin{array}{l}-.094 * * \\
(.046)\end{array}$ & $\begin{array}{l}-.020 \\
(.051 \\
\end{array}$ & $\begin{array}{l}.066^{*} \\
(.037) \\
\end{array}$ \\
\hline \multicolumn{4}{|l|}{ Age } \\
\hline $35-49$ & $\begin{array}{l}.060 \\
(.213)\end{array}$ & $\begin{array}{l}.037 \\
(.204)\end{array}$ & $\begin{array}{l}.088 \\
(.175)\end{array}$ \\
\hline $50-64$ & $\begin{array}{l}-.203 \\
(.211)\end{array}$ & $\begin{array}{l}-110 \\
(.239)\end{array}$ & $\begin{array}{l}-.218 \\
(.180)\end{array}$ \\
\hline Over 65 & $\begin{array}{l}.143 \\
(.304)\end{array}$ & $\begin{array}{l}.047 \\
(.364)\end{array}$ & $\begin{array}{l}.053 \\
(.259)\end{array}$ \\
\hline Gender & $\begin{array}{l}-015 \\
(.140)\end{array}$ & $\begin{array}{l}.259 \\
(.163)\end{array}$ & $\begin{array}{l}.446^{* * * *} \\
(.113)\end{array}$ \\
\hline \multicolumn{4}{|l|}{ Place of Residence } \\
\hline A big city & $\begin{array}{l}.646^{* * *} \\
(.300)\end{array}$ & $\begin{array}{l}.153 \\
(.342)\end{array}$ & $\begin{array}{l}.046 \\
(.247)\end{array}$ \\
\hline Suburbs or outskirts of a big city & $\begin{array}{l}.490 \\
(.214)\end{array}$ & $\begin{array}{l}.175 \\
(.232)\end{array}$ & $\begin{array}{l}.012 \\
(.161)\end{array}$ \\
\hline Country village & $\begin{array}{l}.715^{* * * *} \\
(.216) \\
\end{array}$ & $\begin{array}{l}.204 \\
(.235) \\
\end{array}$ & $\begin{array}{l}.184 \\
(.162)\end{array}$ \\
\hline Farm or home in countryside & $\begin{array}{l}.438 \\
(.307) \\
\end{array}$ & $\begin{array}{l}.072 \\
(.383) \\
\end{array}$ & $\begin{array}{l}.031 \\
(.272) \\
\end{array}$ \\
\hline Religiosity & $\begin{array}{l}.022 \\
(.025) \\
\end{array}$ & $\begin{array}{l}-.022^{* *} \\
(.025) \\
\end{array}$ & $\begin{array}{l}.033 \\
(.021)\end{array}$ \\
\hline \multicolumn{4}{|l|}{ Professional activity } \\
\hline Paid work limited contract & $\begin{array}{l}.228 \\
(.275) \\
\end{array}$ & $\begin{array}{l}.044 \\
(.335) \\
\end{array}$ & $\begin{array}{l}.025 \\
(.229) \\
\end{array}$ \\
\hline Self-employed or working for family business & $\begin{array}{l}-.126 \\
(.253)\end{array}$ & $\begin{array}{l}-.139 \\
(.299) \\
\end{array}$ & $\begin{array}{l}-.295 \\
(.212) \\
\end{array}$ \\
\hline In school or studying & $\begin{array}{l}-.154 \\
(.487) \\
\end{array}$ & $\begin{array}{l}.250 \\
(.495) \\
\end{array}$ & $\begin{array}{l}-.991 * * \\
(.459)\end{array}$ \\
\hline Retired & $\begin{array}{l}-.199 \\
(.259) \\
\end{array}$ & $\begin{array}{l}-.068 \\
(.311)\end{array}$ & $\begin{array}{l}-.169 \\
(.215)\end{array}$ \\
\hline Unemployed & $\begin{array}{l}.384 \\
(.325)\end{array}$ & $\begin{array}{l}.719 * \\
(.386)\end{array}$ & $\begin{array}{l}. .0003 \\
(.343) \\
\end{array}$ \\
\hline Disabled & $\begin{array}{l}.192 \\
(.373)\end{array}$ & $\begin{array}{l}-.513 \\
(.522)\end{array}$ & $\begin{array}{l}-.214 \\
(.343)\end{array}$ \\
\hline Other & $\begin{array}{l}.797 \\
(.633)\end{array}$ & $\begin{array}{l}-.524 \\
(1.17)\end{array}$ & $\begin{array}{l}.389 \\
(.525) \\
\end{array}$ \\
\hline Housewife or houseman & $\begin{array}{l}.203 \\
(.324) \\
\end{array}$ & $\begin{array}{l}.434 \\
(.365) \\
\end{array}$ & $\begin{array}{l}-.109 \\
(.292) \\
\end{array}$ \\
\hline Self-placement of left-right scale & $\begin{array}{l}.063^{*} \\
(.034)\end{array}$ & $\begin{array}{l}.057 \\
(.037)\end{array}$ & $\begin{array}{l}.160 * * * \\
(.039)\end{array}$ \\
\hline Attachment to the European Union & $\begin{array}{l}-.070 * * \\
(.029)\end{array}$ & $\begin{array}{l}-.129 * * * \\
(.032)\end{array}$ & $\begin{array}{l}-.175^{* * * *} \\
(.024)\end{array}$ \\
\hline Satisfaction with the national government & $\begin{array}{l}-.055^{*} \\
(.033)\end{array}$ & $\begin{array}{l}-.047 \\
(.036)\end{array}$ & $\begin{array}{l}.076 \\
(.027)\end{array}$ \\
\hline Participation in civic and social activities & $\begin{array}{l}.022 \\
(.075) \\
\end{array}$ & $\begin{array}{l}.011 \\
(.077) \\
\end{array}$ & $\begin{array}{l}.106^{*} \\
(.063) \\
\end{array}$ \\
\hline Influence the political system & $\begin{array}{l}-.133 \\
: 085) \\
\end{array}$ & $\begin{array}{l}-.085 \\
(.093)\end{array}$ & $\begin{array}{l}-212 * * * \\
(.069)\end{array}$ \\
\hline Constant & $\begin{array}{l}.020 \\
(.507) \\
\end{array}$ & $\begin{array}{l}.274 \\
(.512) \\
\end{array}$ & $\begin{array}{l}-2.46^{* * * *} \\
(.380) \\
\end{array}$ \\
\hline Pseudo Rsquared & .11 & & \\
\hline $\mathrm{N}$ & 2403 & & \\
\hline
\end{tabular}

Note: ${ }^{* * *} p<.01,{ }^{* *} p<.05,{ }^{*} p<.1$. We also run our multinomial logistic model with country dummies, and the results mimic those presented in Table 4 and Figures 2 to 12. The same applies if we exclude Hungary and Poland, whose two far-right parties Fidesz and Pis are not always coded as far right? 
Figure 1: The effect of education on different types of far-right voters

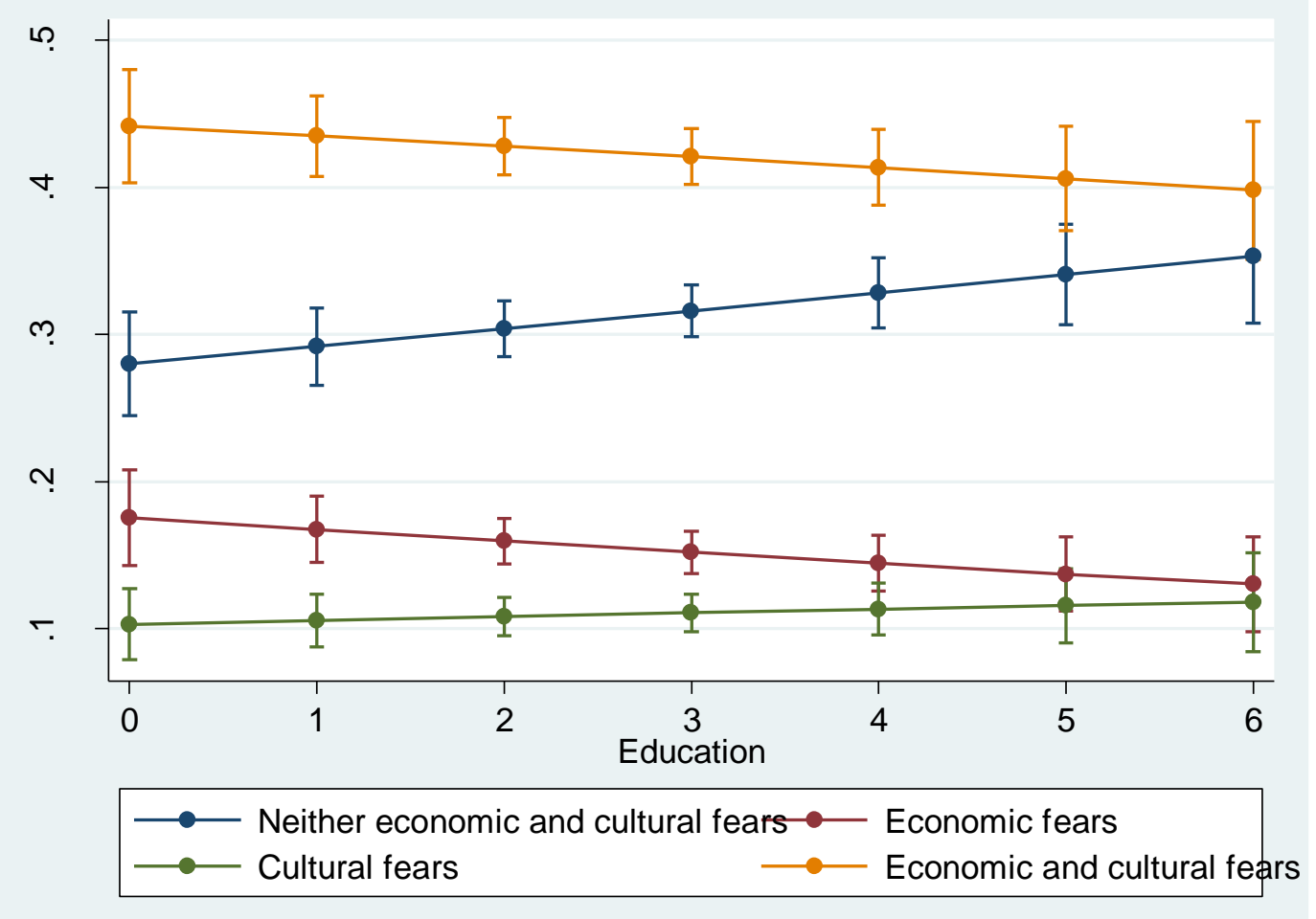

Figure 2: The effect of age on different types of far-right voters

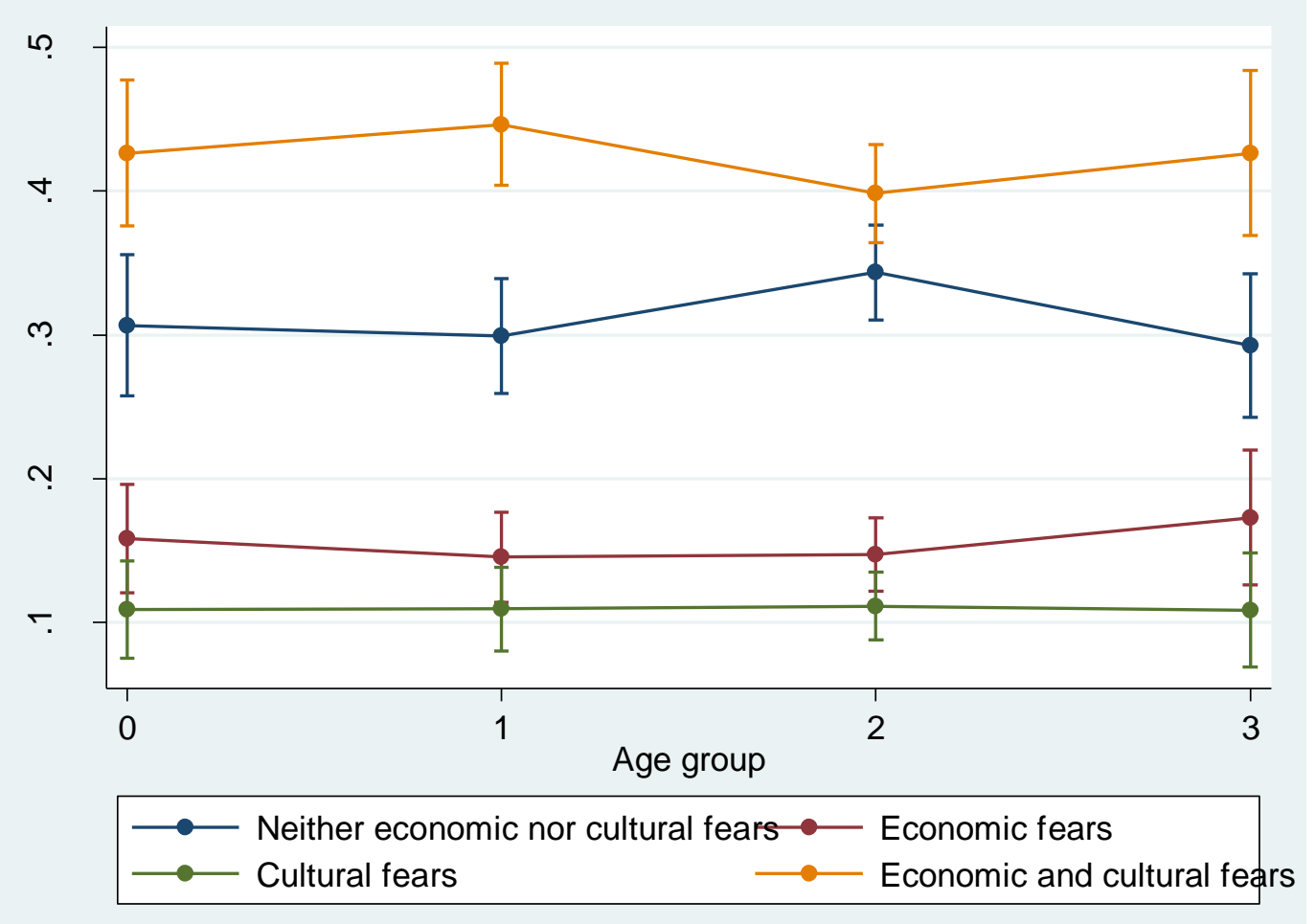


Figure 3: The effect of gender on different types of far-right voters

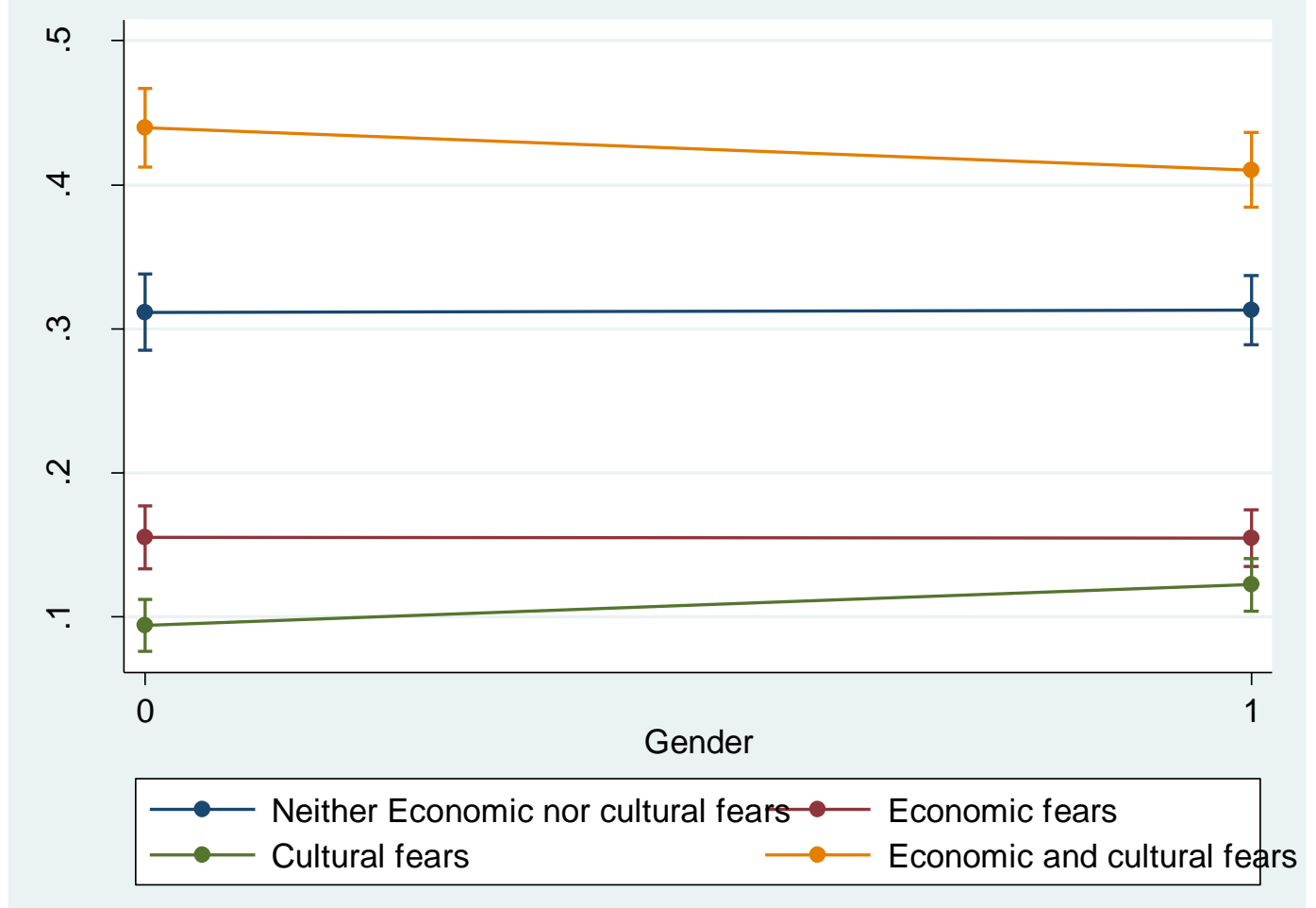

Figure 4: The effect of the place of residence on different types of far-right voters

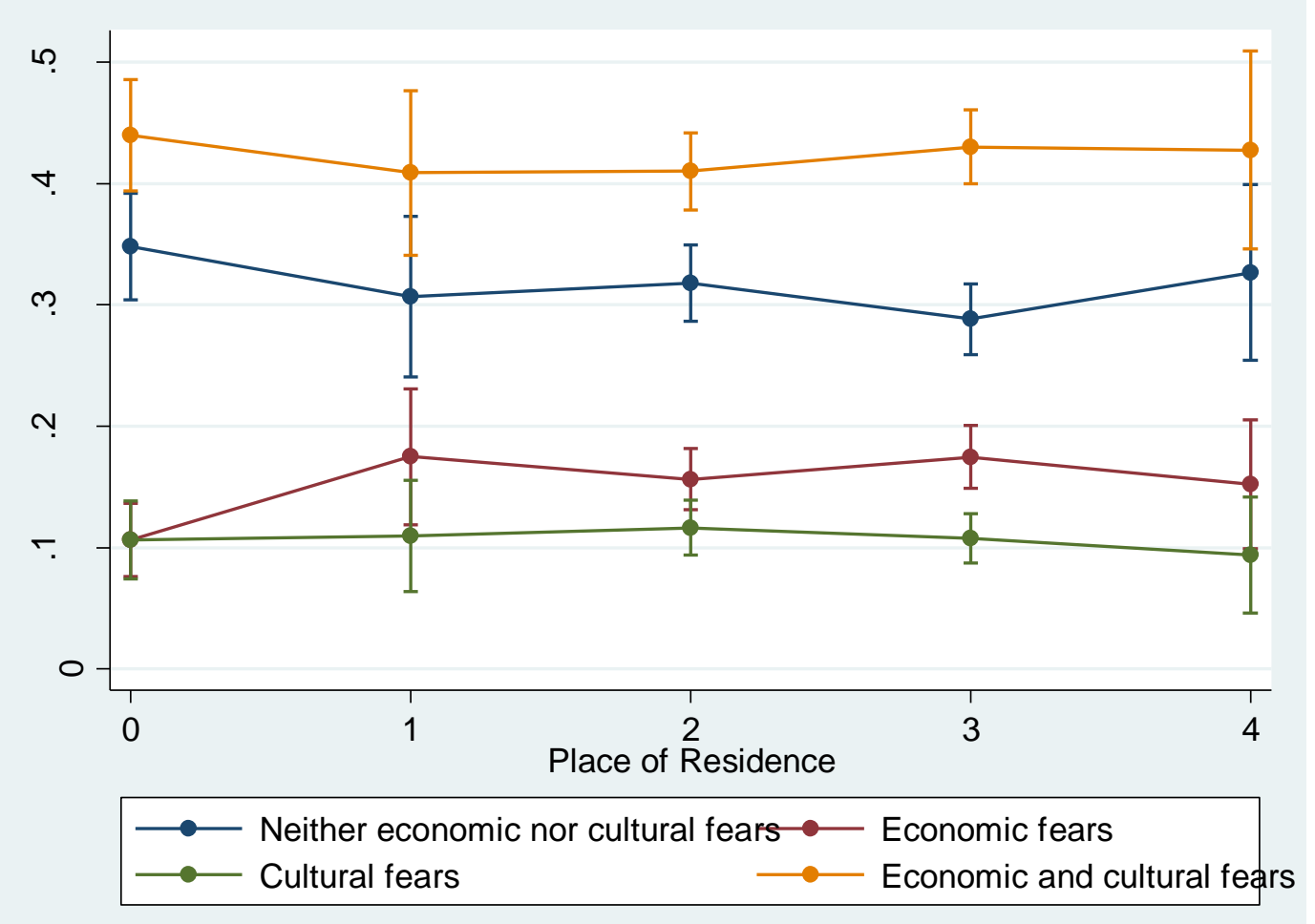


Figure 5: The effect of religiosity on different types of far-right voters

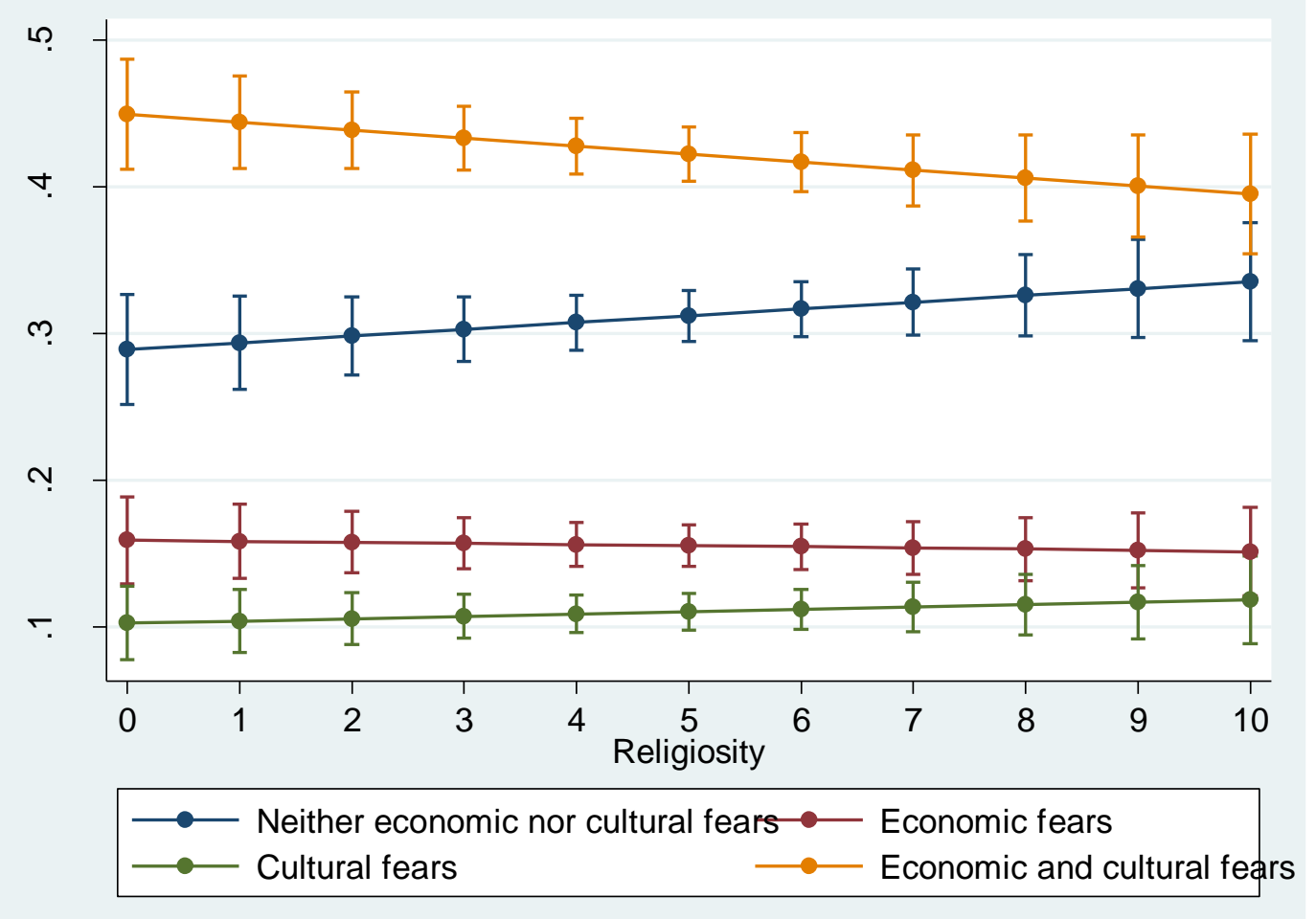

Figure 6: The effect of professional activity on different types of far right voters

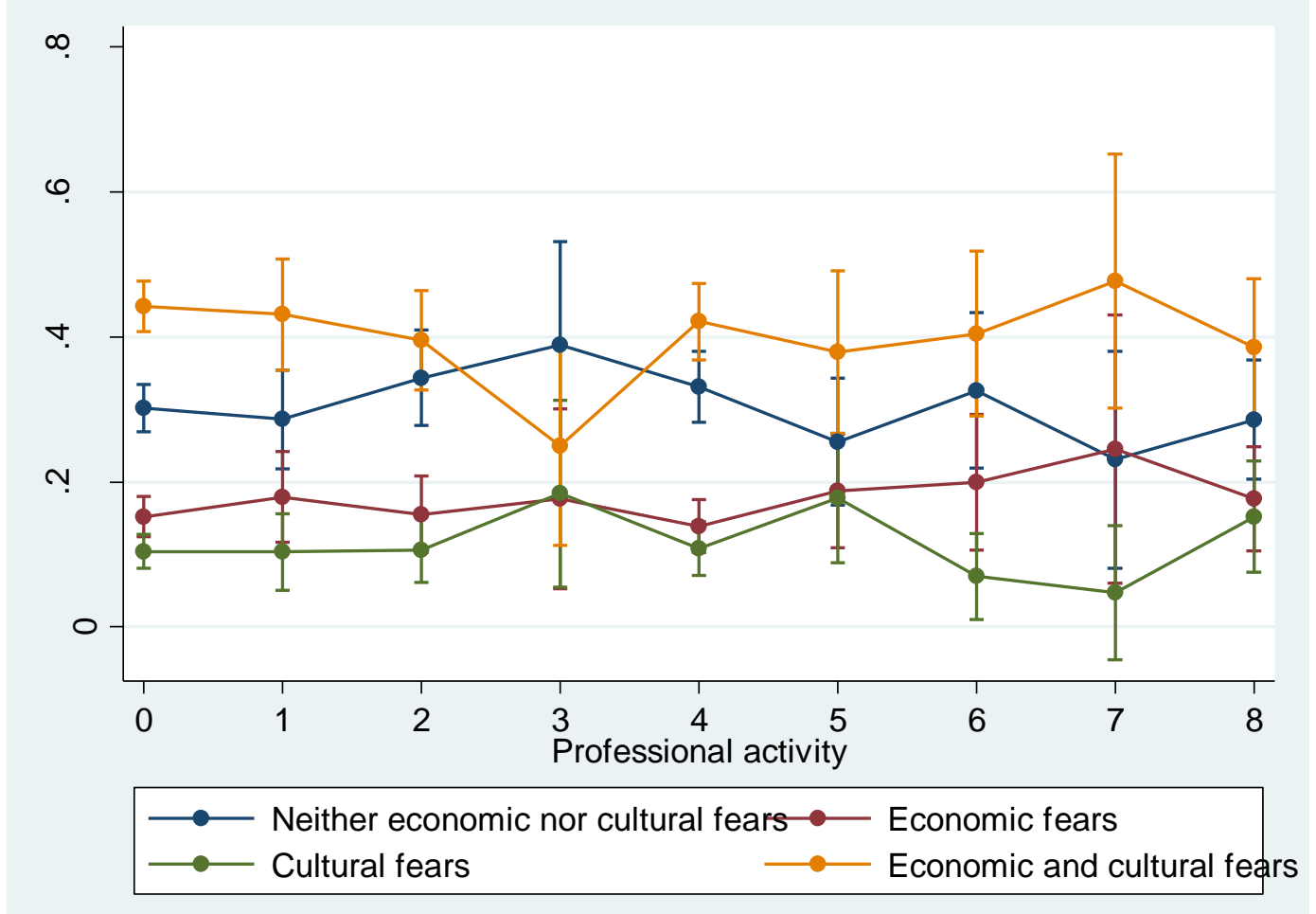


Figure 7: The effect of left-right placement on different types of far-right voters

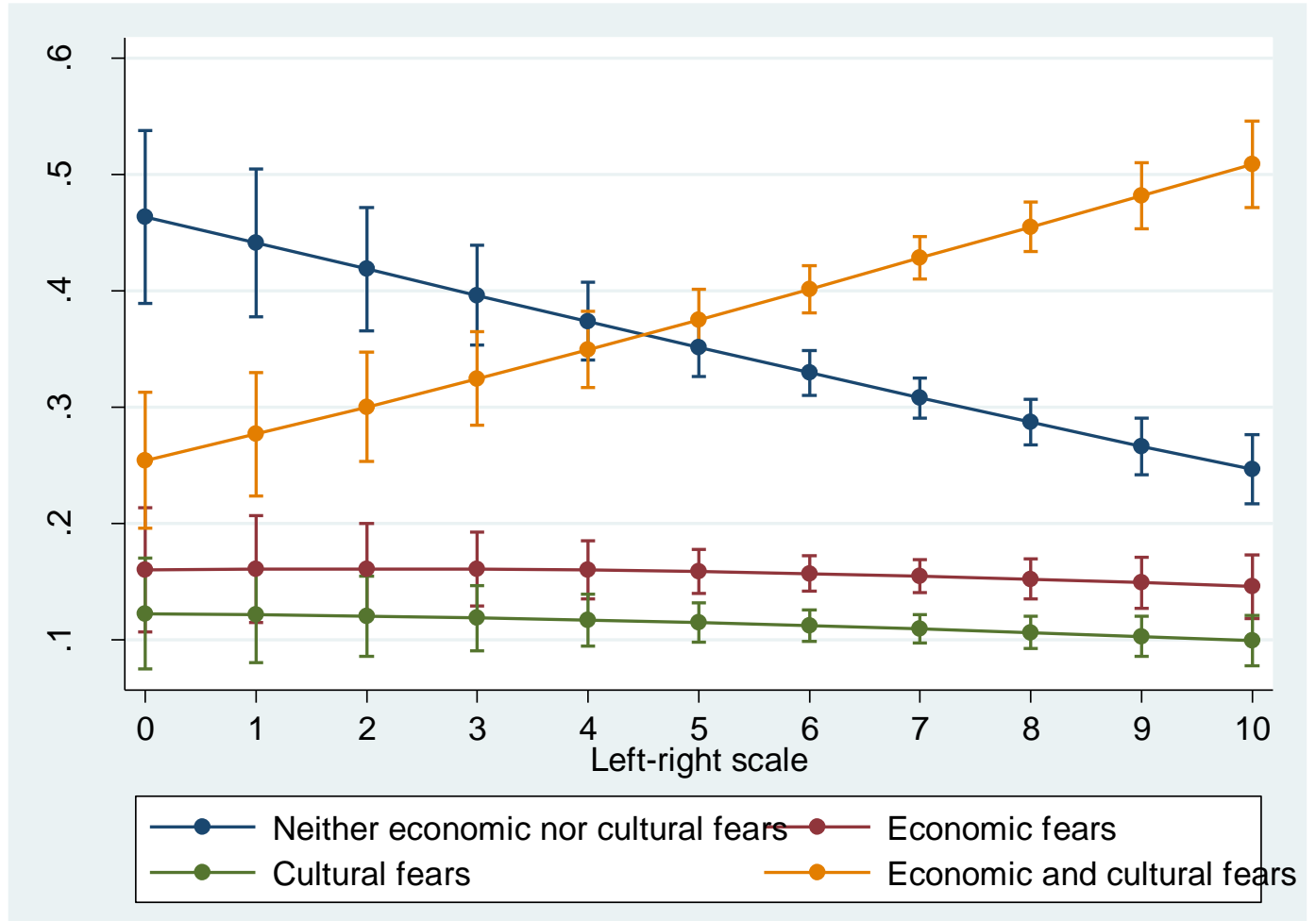

Figure 8: The effect of attachment toward the EU on different types of far-right voters

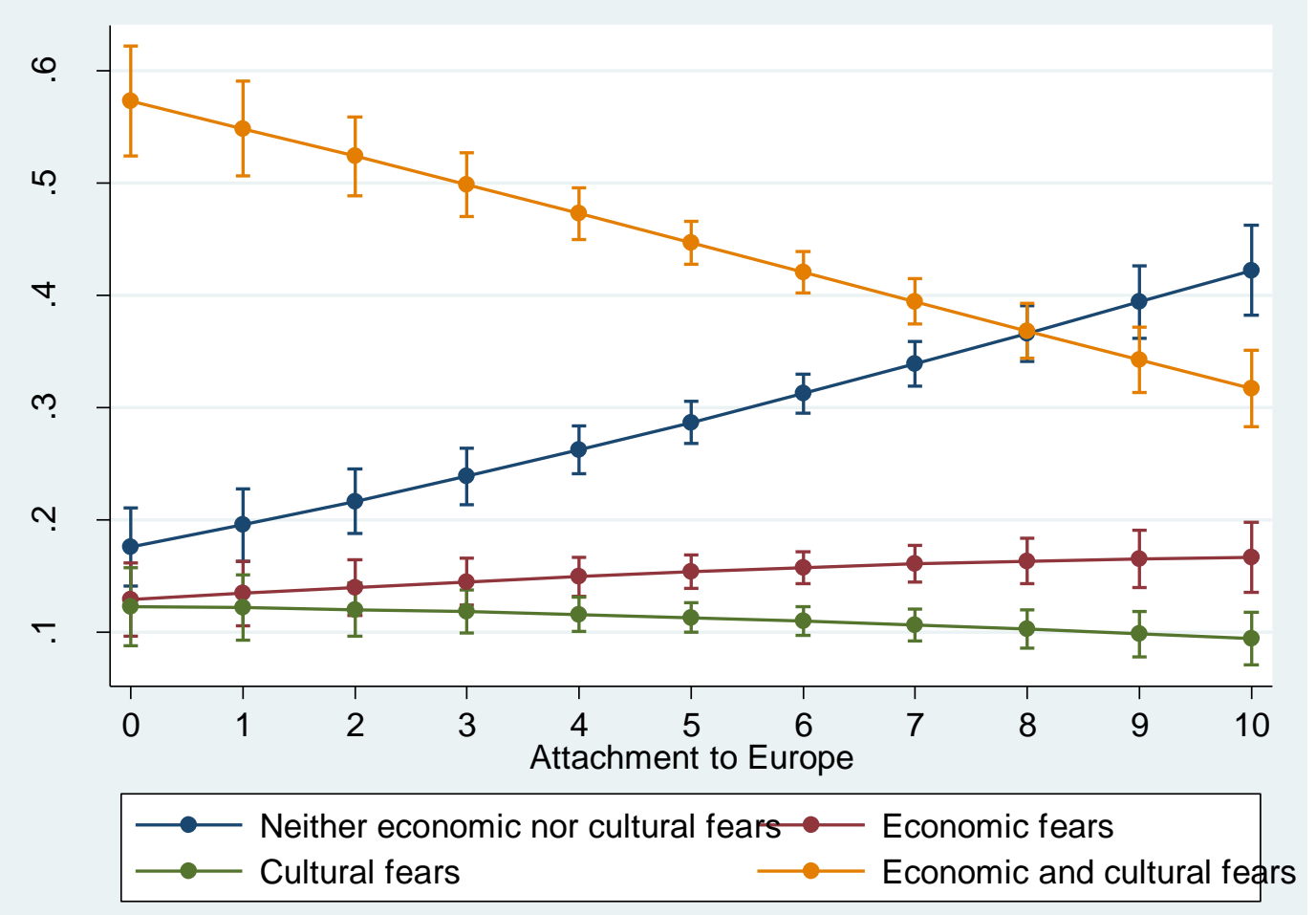


Figure 9: The effect of satisfaction with the national government on different types of far-right voters

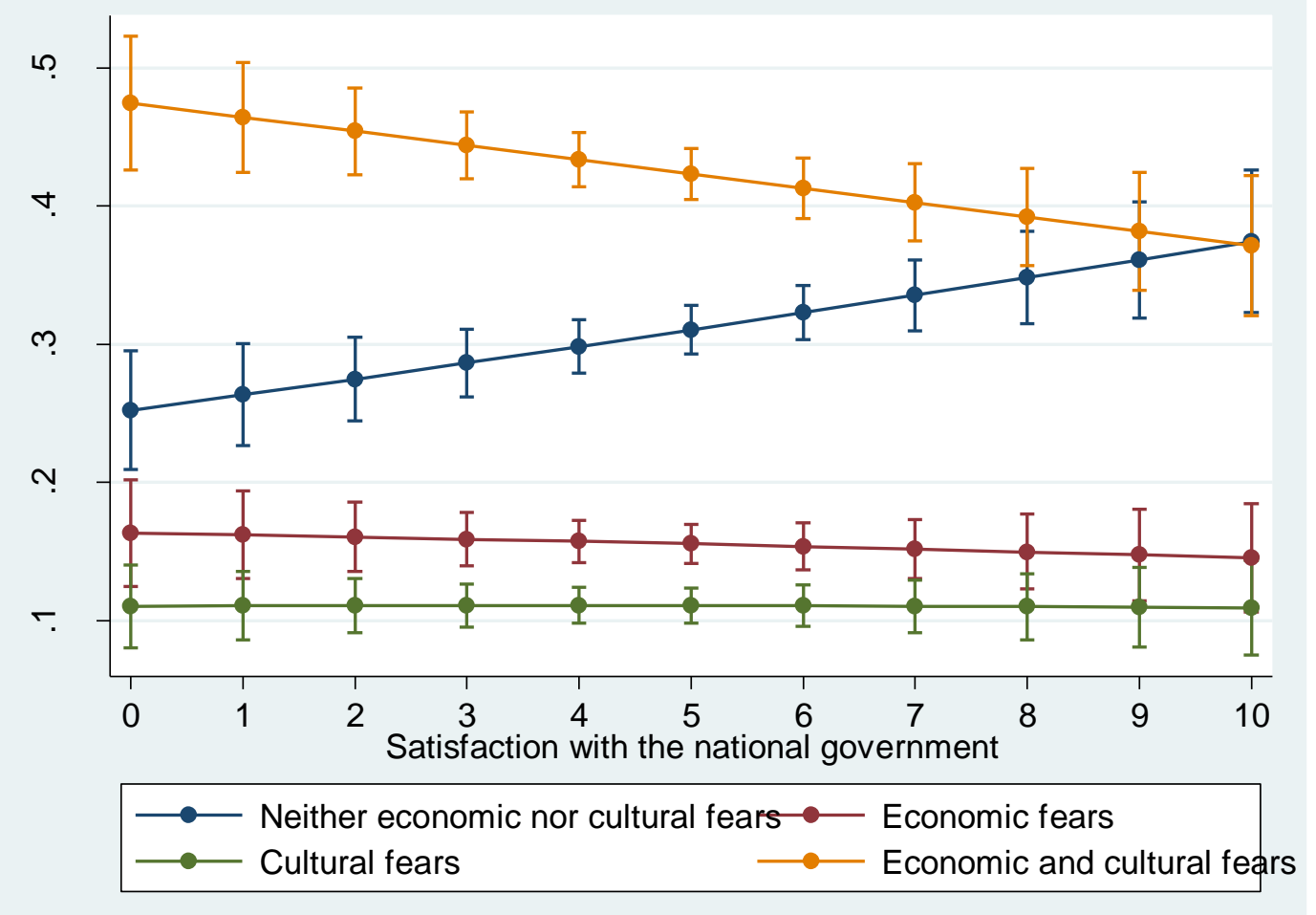

Figure 10: The effect of participation in civic and social activities on different types of far-right voters

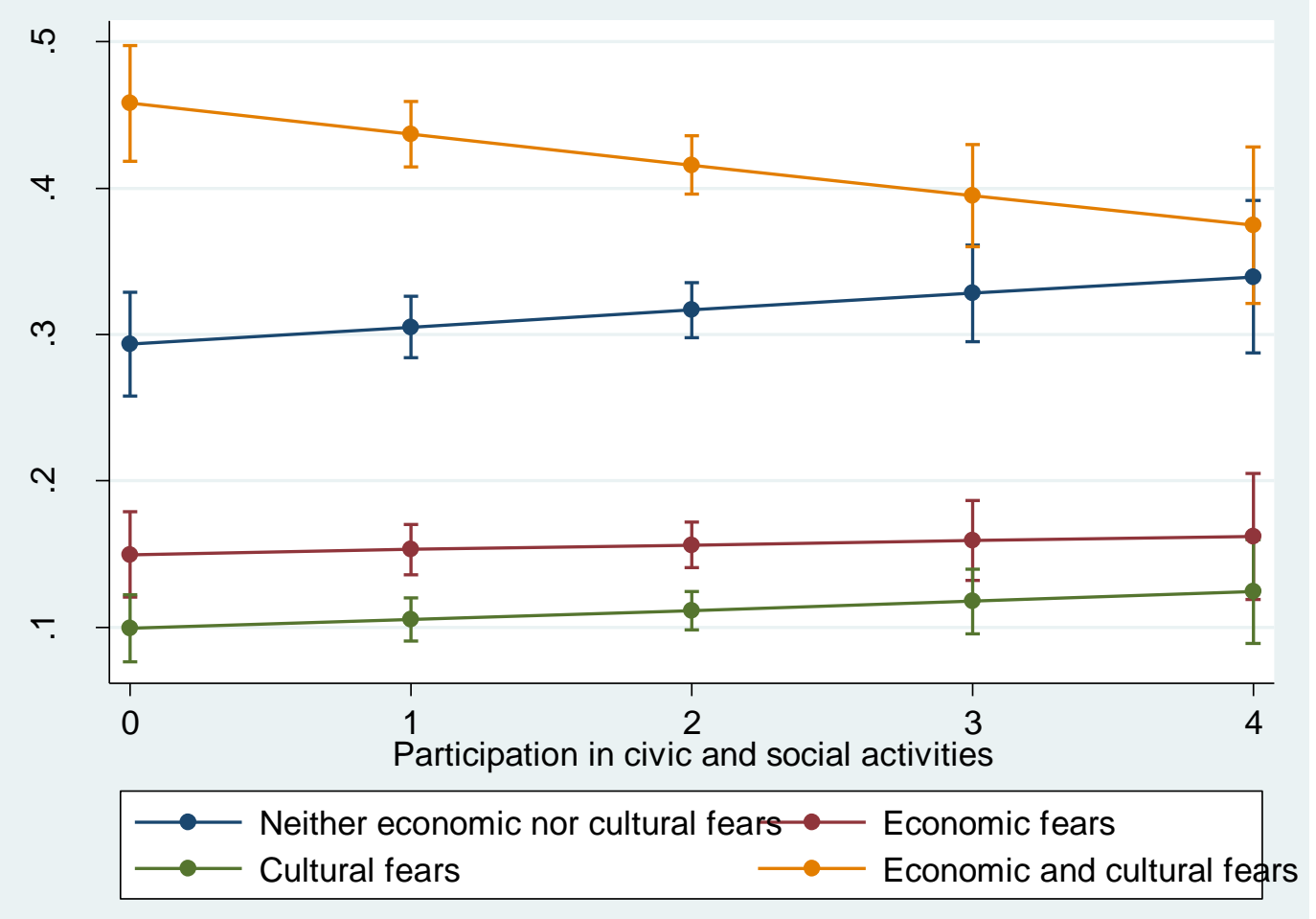


Figure 11: The effect of the self-perceived possibility to influence the political system on different types of far-right voters

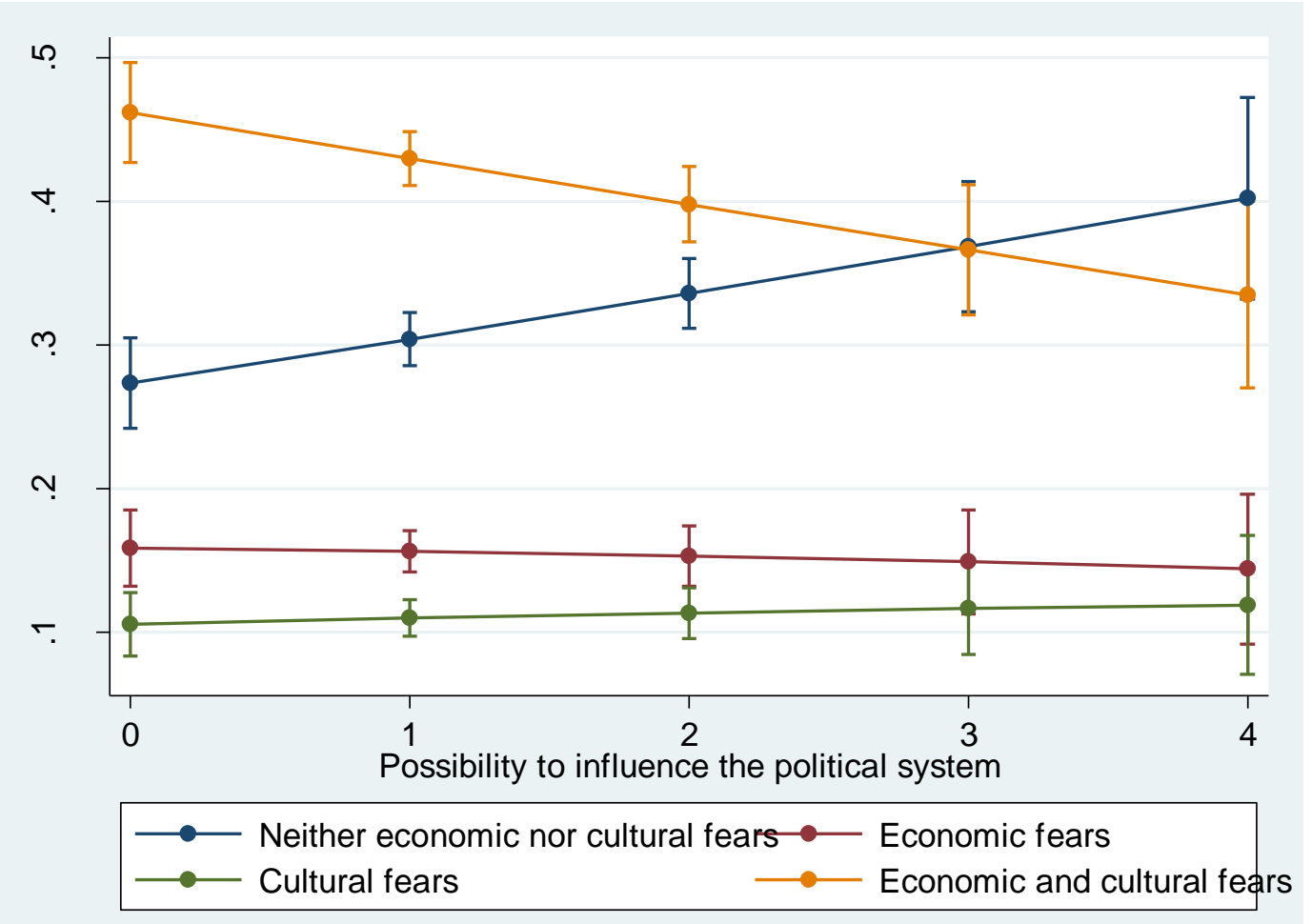




\section{Appendix}

Table A1: Operationalisation of Independent variables

\begin{tabular}{|c|c|}
\hline Variable Name & Operationalisation \\
\hline Education & $\begin{array}{l}7 \text { value scale ranging from } 0 \text { less then lower secondary } \\
\text { education to } 6 \text { higher tertiary education }\end{array}$ \\
\hline Age & $\begin{array}{l}4 \text { value ordinal variable comprising the four categories } 18 \\
\text { to } 34,35 \text { to } 49,50 \text { to } 64 \text {; and above } 65\end{array}$ \\
\hline Gender & Dummy variable coded 0 for women and 1 for men \\
\hline Place of residence & $\begin{array}{l}\text { We distinguish five categories: (1) Living in a big city, (2) } \\
\text { Suburbs or outskirts of a big city, (3) Town or small city, } \\
\text { (4) village in the countryside, (5) farm or home in the } \\
\text { countryside. Since we cannot necessarily assume a linear } \\
\text { relationship between the variable place of residency and } \\
\text { far right electoral support, we create four dummy } \\
\text { variables with living in a big city serving as the reference } \\
\text { category }\end{array}$ \\
\hline Religiosity & $\begin{array}{l}11 \text { value scale ranging from not at all religious to very } \\
\text { religious }\end{array}$ \\
\hline Professional Activity & $\begin{array}{l}\text { We distinguish } 9 \text { professional categories: (1) paid work } \\
\text { unlimited contract, (2) paid work limited contract, (3) self- } \\
\text { employed or working for family business, (4) in school or } \\
\text { studying, (5) retired, (6) unemployed, ( } 7 \text { ) disabled, (8) } \\
\text { other, (9) housewife or houseman. To distinguish these } 9 \\
\text { activities, we create } 8 \text { dummy variable, with the first } \\
\text { category paid work unlimited contract serving as the } \\
\text { reference category }\end{array}$ \\
\hline Self-placement on a left-right scale & $\begin{array}{l}11 \text { value scale ranging from left (coded } 0 \text { ) to right (coded } \\
10)\end{array}$ \\
\hline Attachment to the European Union & $\begin{array}{l}11 \text { value scale ranging from not emotionally attached } \\
\text { (coded } 0) \text { to (10) very emotionally attached }\end{array}$ \\
\hline Satisfaction with the national government & $\begin{array}{l}11 \text { value scale ranging from extremely dissatisfied (coded } \\
0) \text { to (10) very satisfied }\end{array}$ \\
\hline Participation in social and civic activities & $\begin{array}{l}5 \text { value ordinal variable (coded } 0 \text { to } 4 \text { ) ranging from much } \\
\text { less than most to much more than most }\end{array}$ \\
\hline Influence the political system & $\begin{array}{l}\text { ordinal variable coded } 0 \text { for individuals, who think that } \\
\text { the political system does not at all allow people to have an } \\
\text { influence on politics, to } 4 \text { the political system allows a } \\
\text { great deal of people to have an influence on the political } \\
\text { system. }\end{array}$ \\
\hline
\end{tabular}


Table A2: Logistic regression model measuring the influence of economic and cultural fears on the far right vote

\begin{tabular}{|c|c|}
\hline Economic fears & $-.108 * * * \quad(.020)$ \\
\hline Cultural fears & $-.082 * * * \quad(.018)$ \\
\hline Interaction between economic and cultural fears & $-.151 * * * \quad(.004)$ \\
\hline Education & $-144 * * * \quad(.015)$ \\
\hline \multicolumn{2}{|l|}{ Age [reference category: ADD] } \\
\hline $35-49$ & $-.148 * *$ \\
\hline $50-64$ & $-.267 * * * \quad(.077)$ \\
\hline Over 65 & $.877 * * \quad(.111)$ \\
\hline Gender & $.175 * * *$ \\
\hline \multicolumn{2}{|l|}{ Place of residence } \\
\hline A big city & $-3.98 * * * \quad(.229)$ \\
\hline Suburbs or outskirts of a big city & $(.071)$ \\
\hline Country village & $(.071)$ \\
\hline Farm or home in countryside & $-.441 * * * \quad(.110)$ \\
\hline Religiosity & $.013 * * * \quad(.008)$ \\
\hline \multicolumn{2}{|l|}{ Professional activity } \\
\hline Paid work limited contract & $(.107)$ \\
\hline Self-employed or working for family business & $-.355 * * \quad(.093)$ \\
\hline In school or studying & $-.632 * * * \quad(.180)$ \\
\hline Retired & $.285 * * * \quad(.093)$ \\
\hline Unemployed & $(.128)$ \\
\hline Disabled & $(.147)$ \\
\hline Other & $(.255)$ \\
\hline Housewife or houseman & $-.263 * *$ \\
\hline Self-placement of left-right scale & $.344 * * * \quad(.012)$ \\
\hline Attachment to the European Union & $(.010)$ \\
\hline Satisfaction with the national government & $.079 * * * \quad(.011)$ \\
\hline Participation in civic and social activities & $(.027)$ \\
\hline Constant & $-2.50 * * * \quad(.153)$ \\
\hline Pseudo Rsquared & .18 \\
\hline
\end{tabular}


Table A3: List of far-right parties included in our analysis

\begin{tabular}{|l|l|}
\hline Country & Far right party \\
\hline Austria & Freedom Party of Austria (FPÖ) \\
\hline Austria & Alliance for the Future of Austria (BZÖ) \\
\hline Belgium & Vlams Belang (VB) \\
\hline Czech Republic & Workers Party of Socialist Justice (DSSS) \\
\hline Denmark & Danish Peoples' Party (DF) \\
\hline Finland & Finns Party (PS) \\
\hline France & French National Front (FN) \\
\hline France & Movement for France (MPF) \\
\hline Germany & National Democratic Party of Germany (NPD) \\
\hline Germany & The Republicans (REP) \\
\hline Hungary & Movement for a Better Hungary (Jobbik) \\
\hline Hungary & Hungarian Civic Alliance (Fidesz) \\
\hline Italy & Lega Nord (LN) \\
\hline Lithuania & Order and Justice (TT) \\
\hline Netherlands & Party for Freedom (FPVV) \\
\hline Norway & Progress Party (FrP) \\
\hline Poland & Law and Justice (PiS) \\
\hline Poland & Congress of the New Right (KPN) \\
\hline Poland & League of Polish Families (LPR) \\
\hline Portugal & National Renovator Party (PNR) \\
\hline Sweden & Sweden Democrats (SD) \\
\hline
\end{tabular}


Figure A(1): Education levels across different types of far right voters
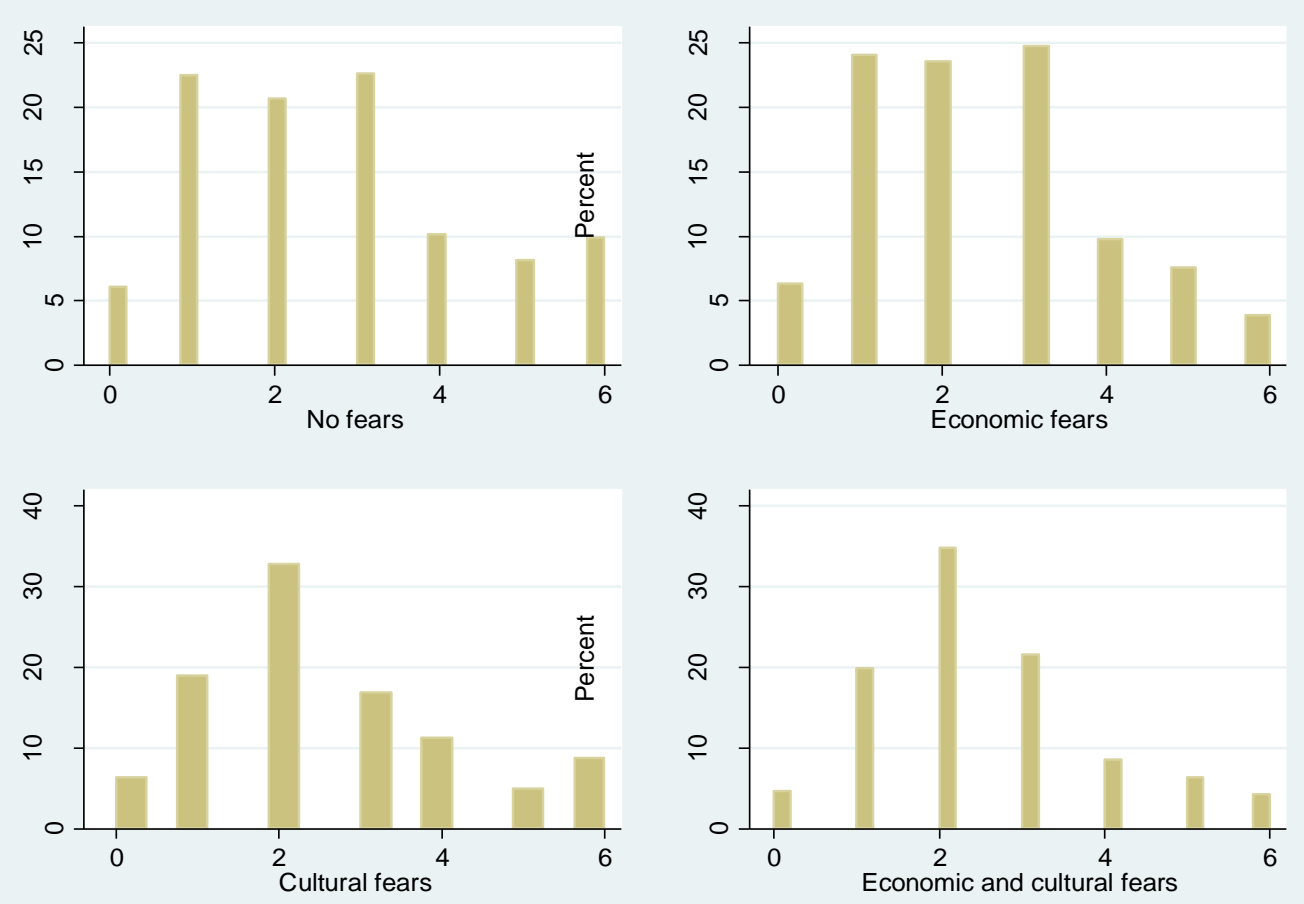

Figure A(2): Age differences across different types of far right voters (Graph 1: 18 to 35; graph 2: 36 to 50; graph 3: 51-65; graph 466 and over)
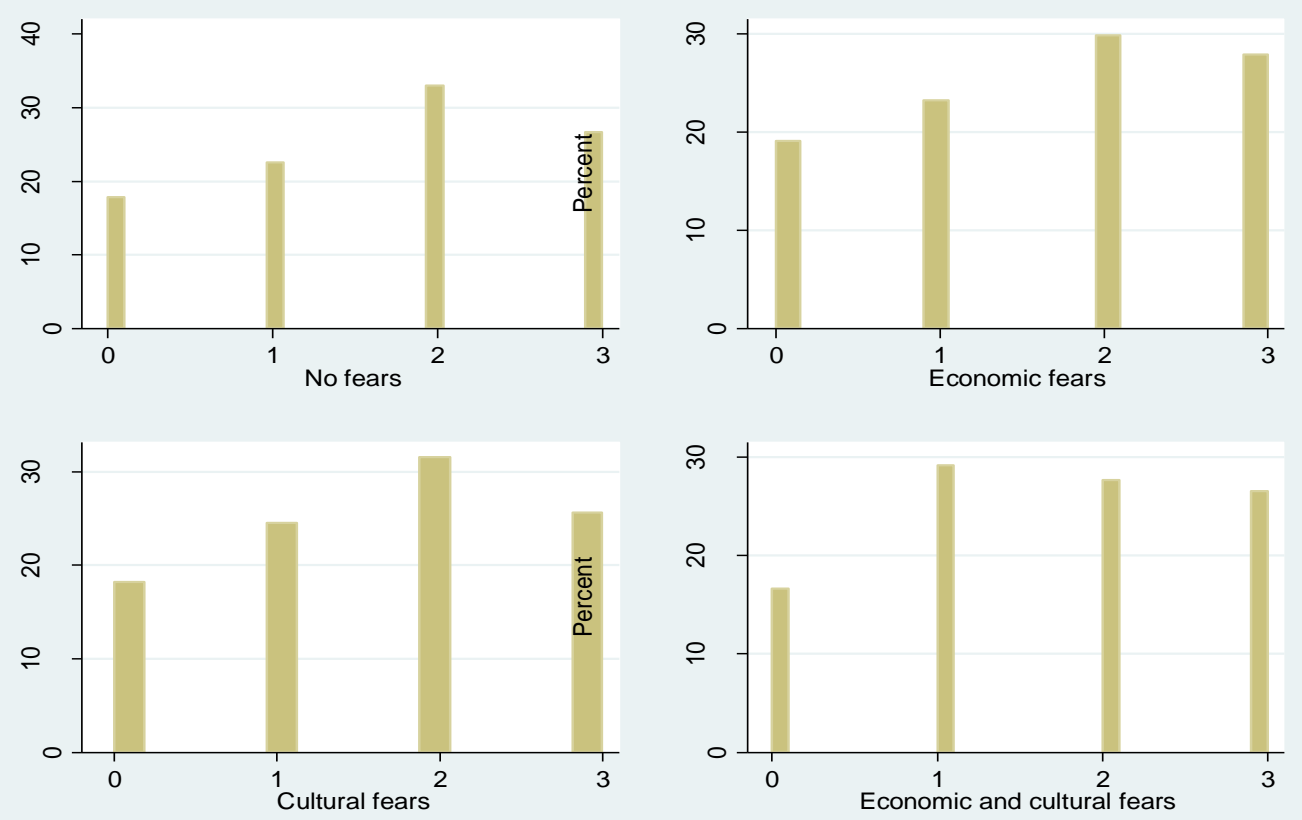
Figure A(3): Gender differences across different types of far right voters (left bar are women, the right bar are men)
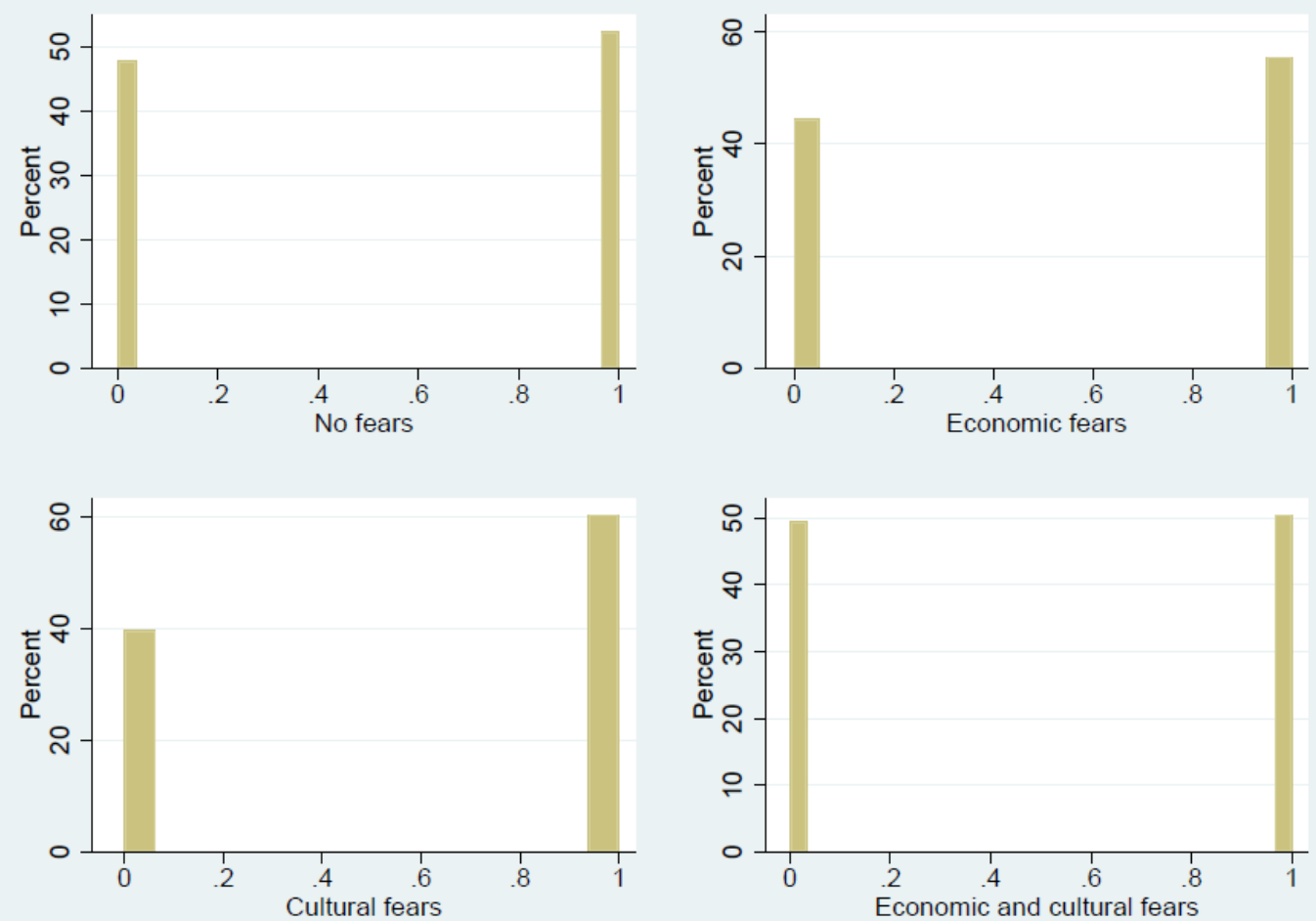

Figure A(4): Differences in the place of residence across different types of far right voters (rural to urban)
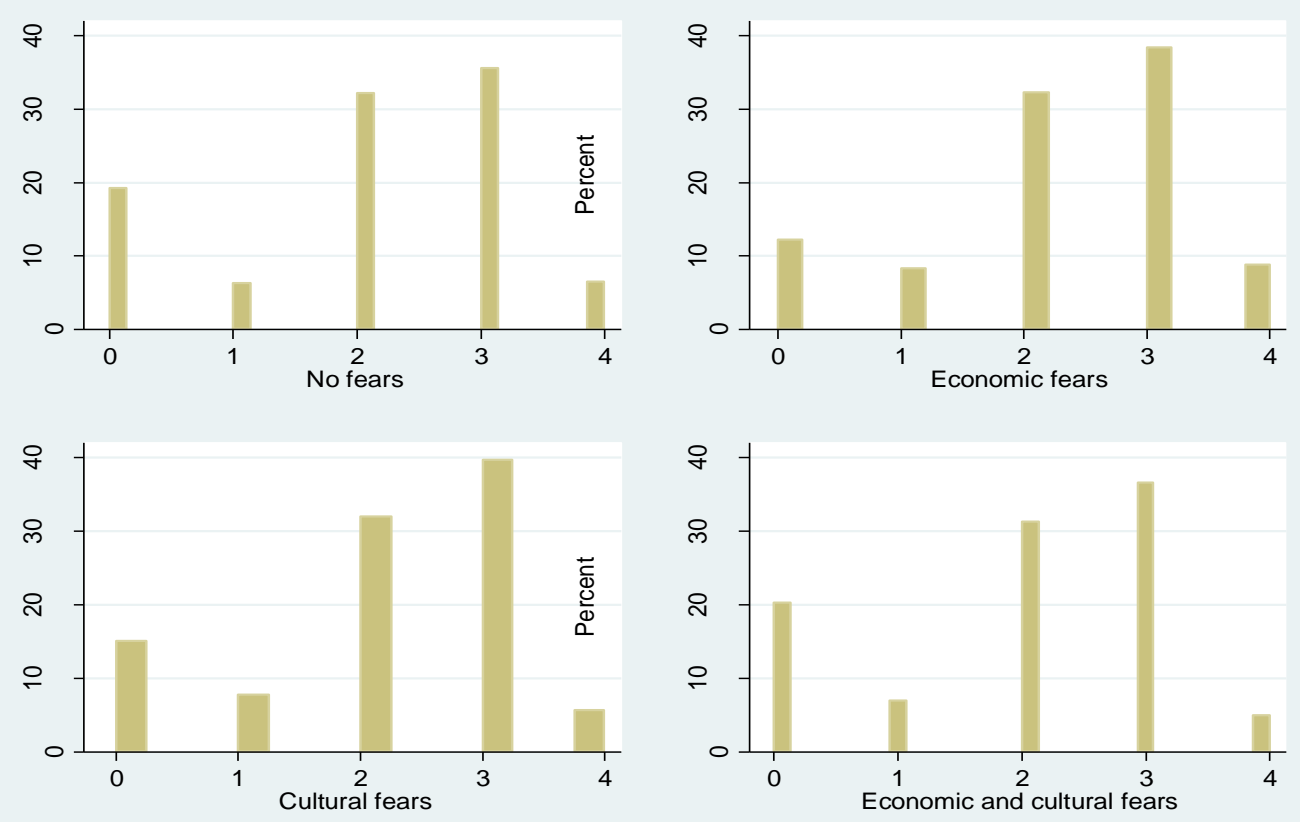
Figure A(5): Religiosity and different types of far right voters
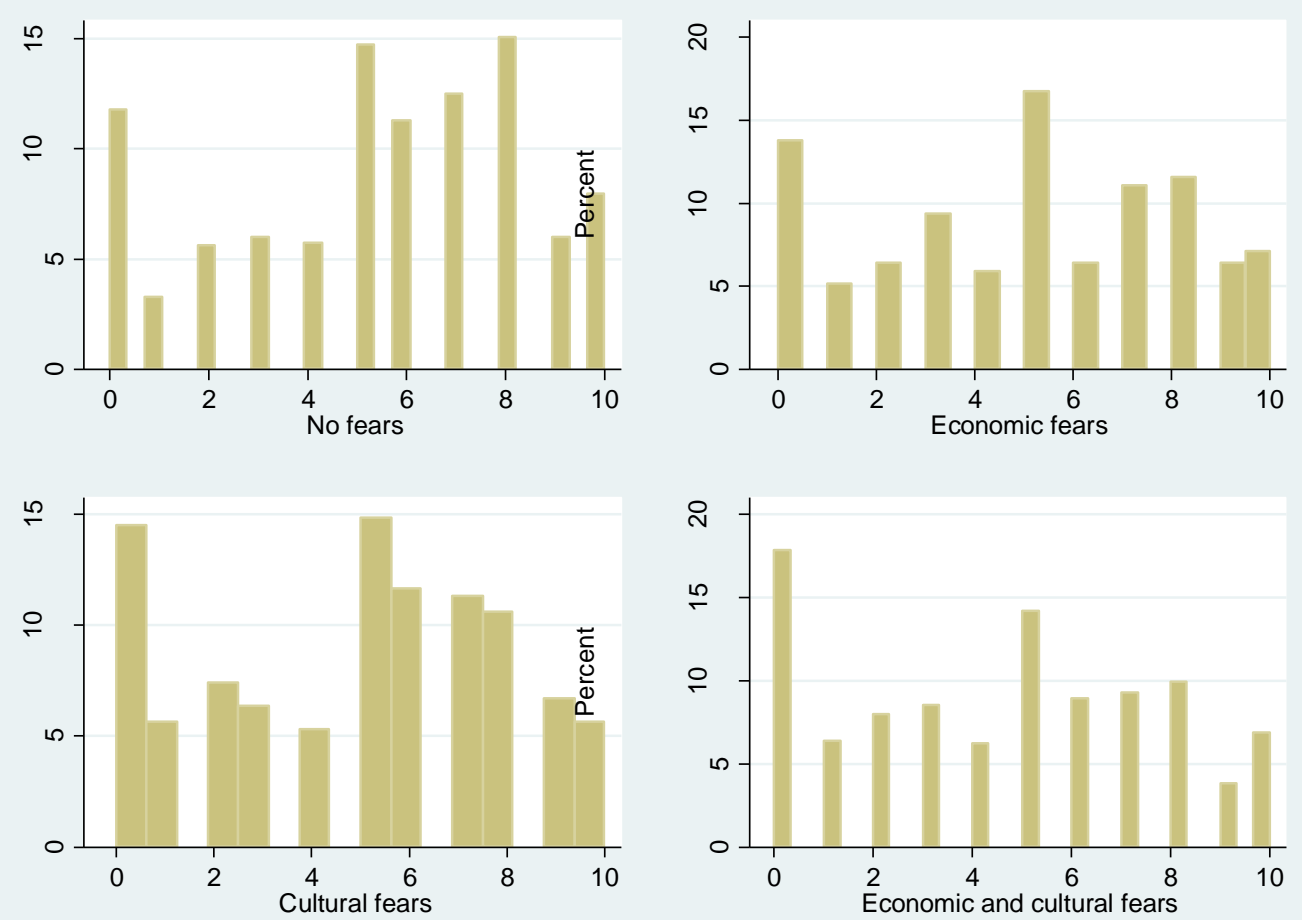

Figure A(6): Different professional activities across different types of far right voters
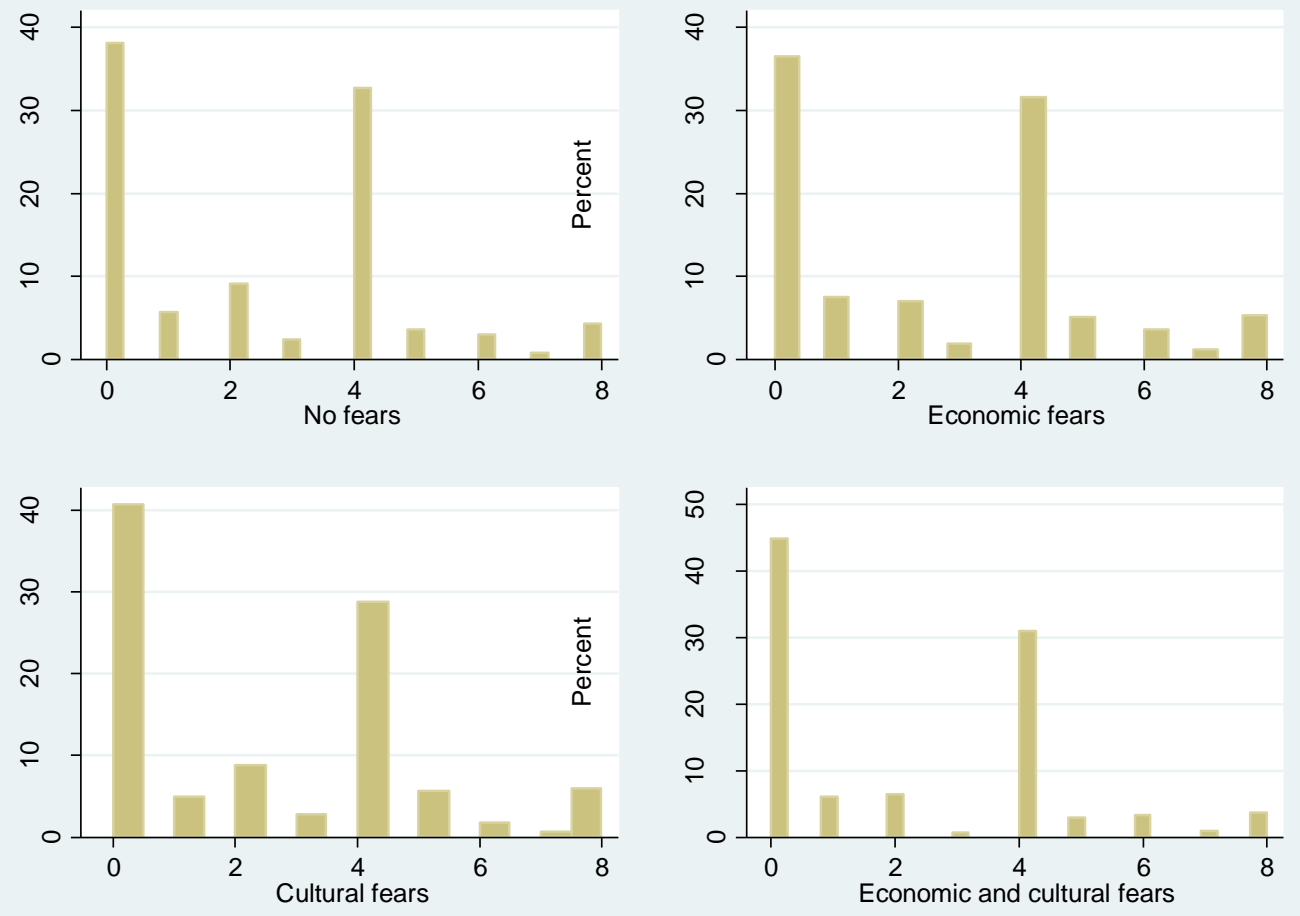
Figure A(7): Left-right placement across different types of far right voters
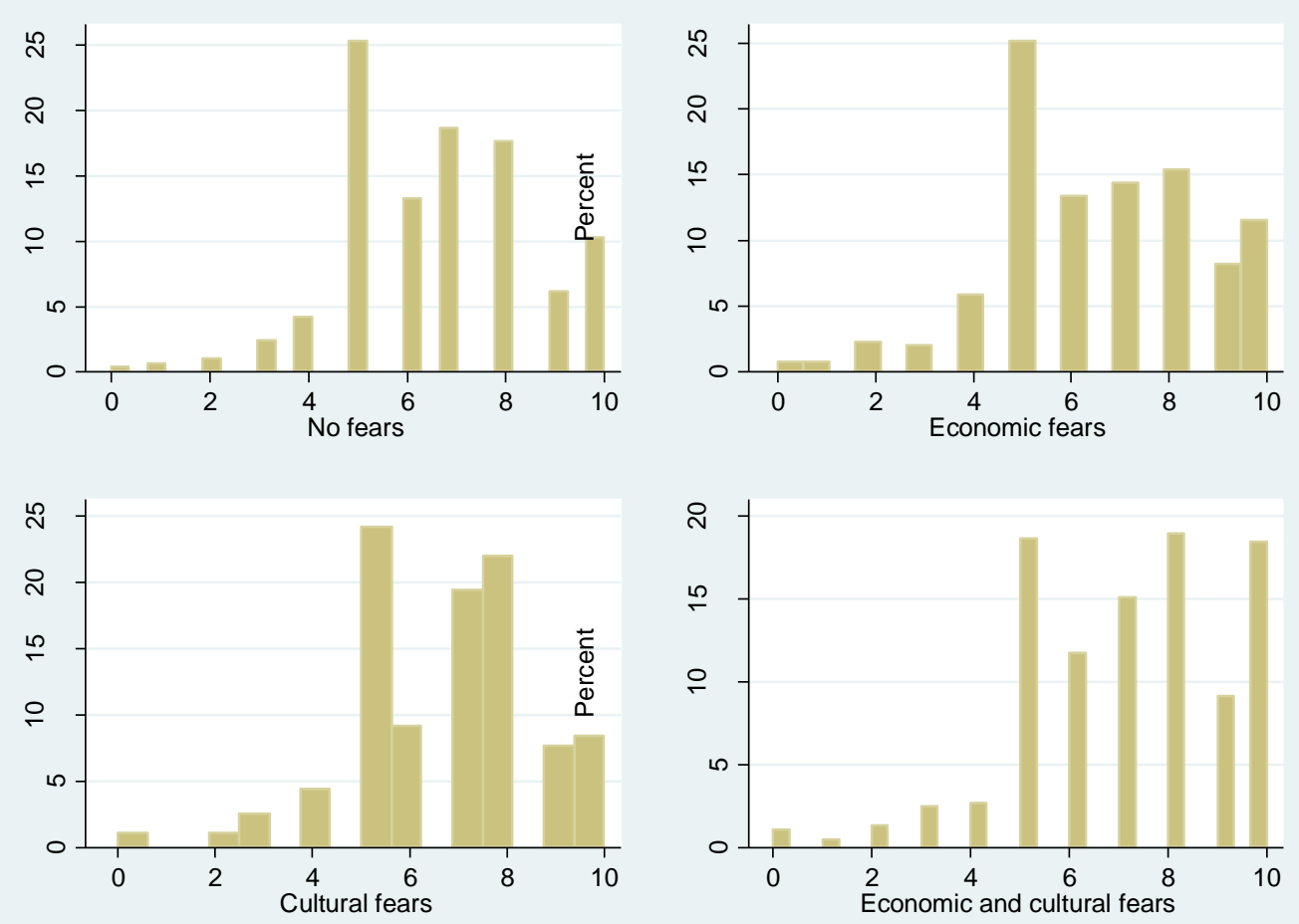

Figure A(8): Attachment to the EU across different types of far right voters
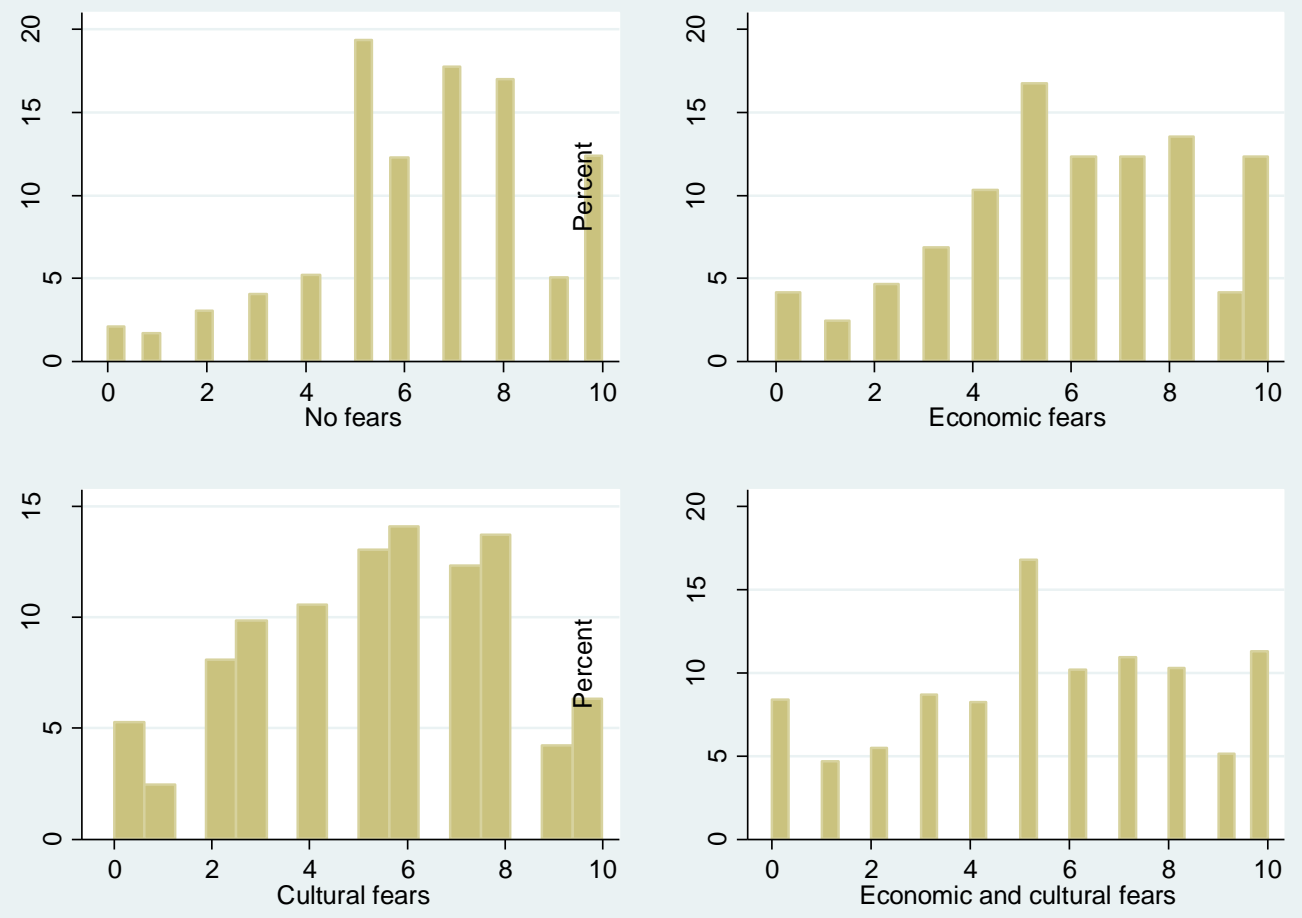
Figure A(9): Satisfaction with the national government across different types of far right voters
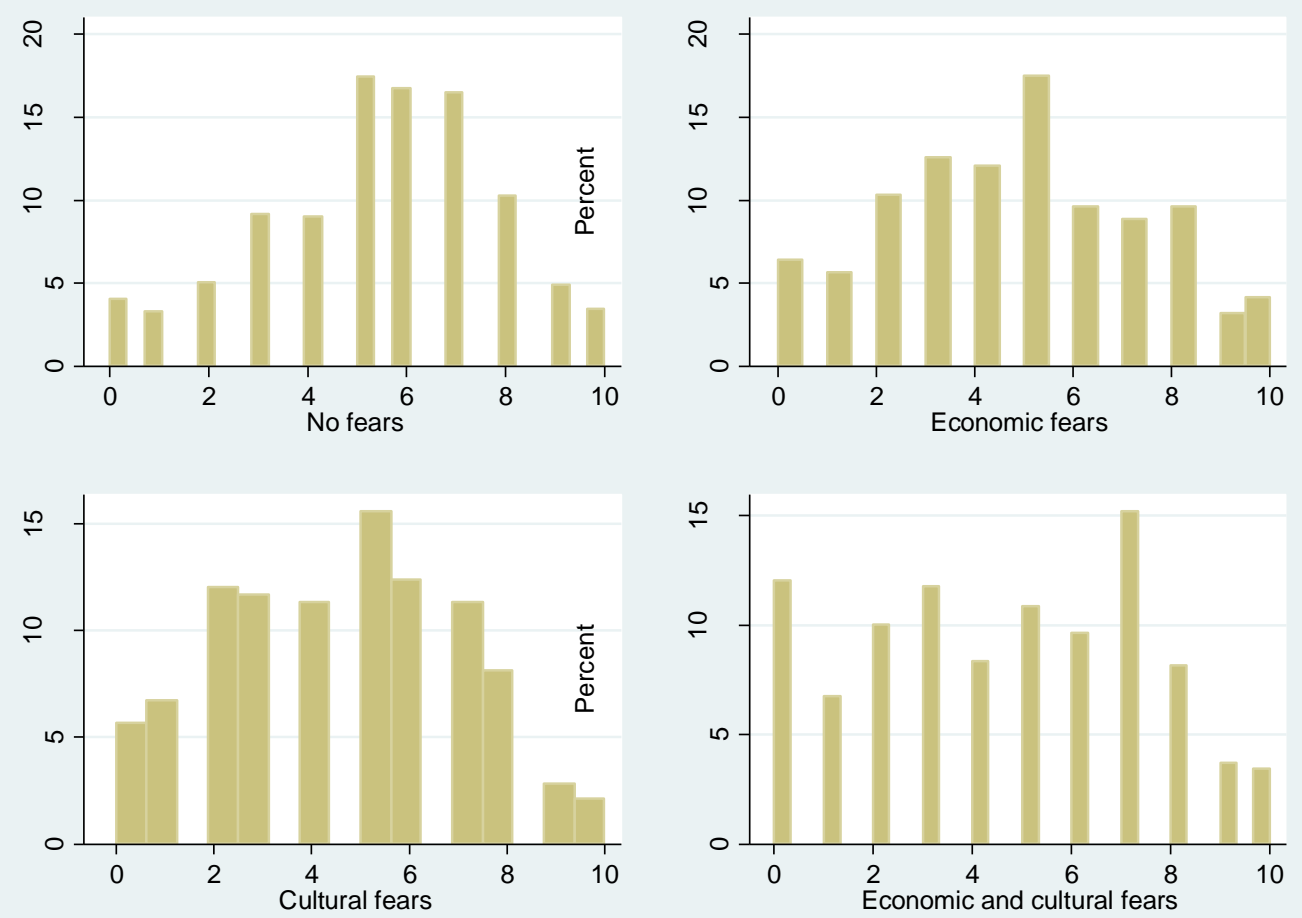

Figure A(10): Participation in civic and social activities across different types of far right voters
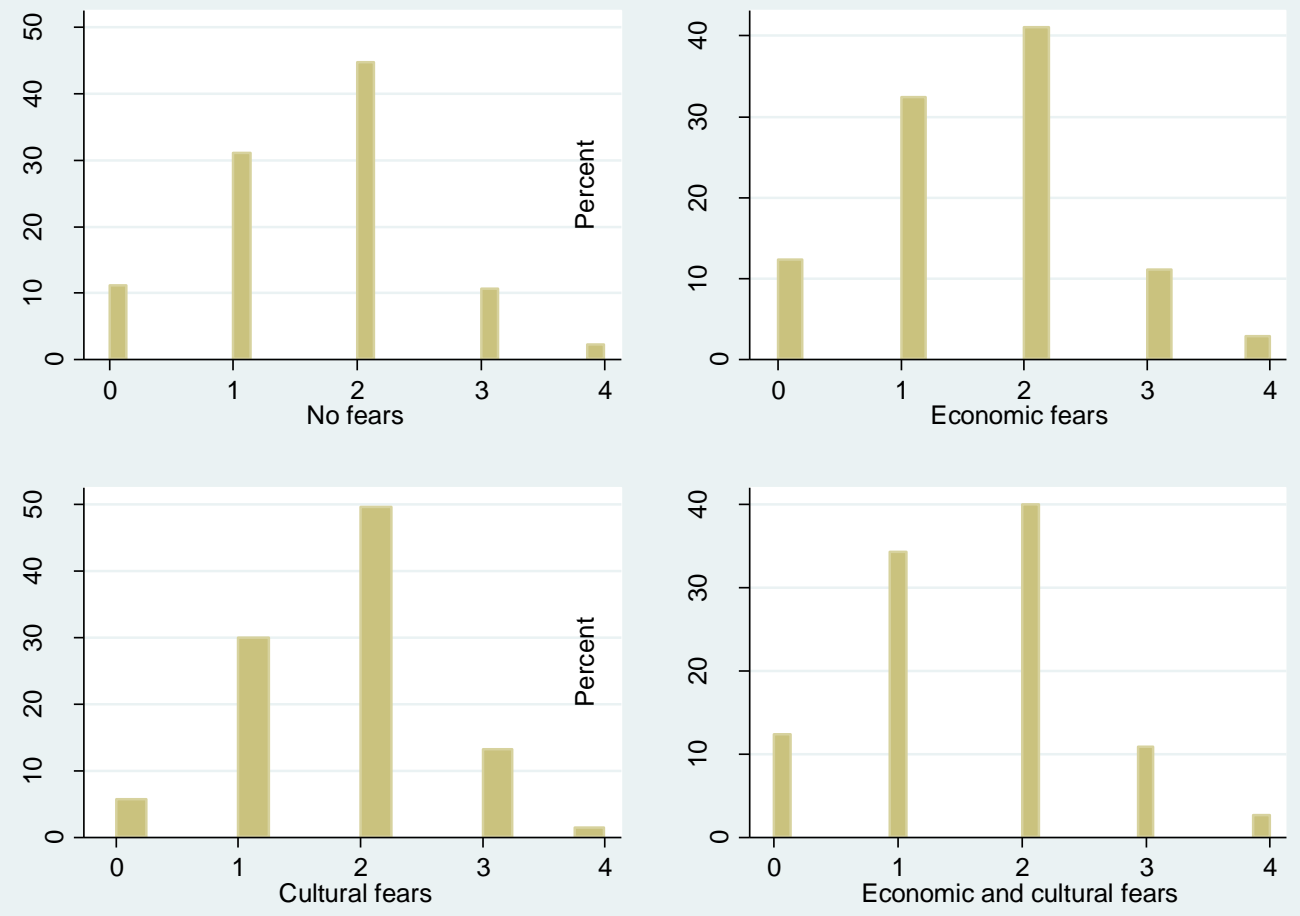
Figure A11: The perceived possibility to influence the political system across different types of far-right voters.
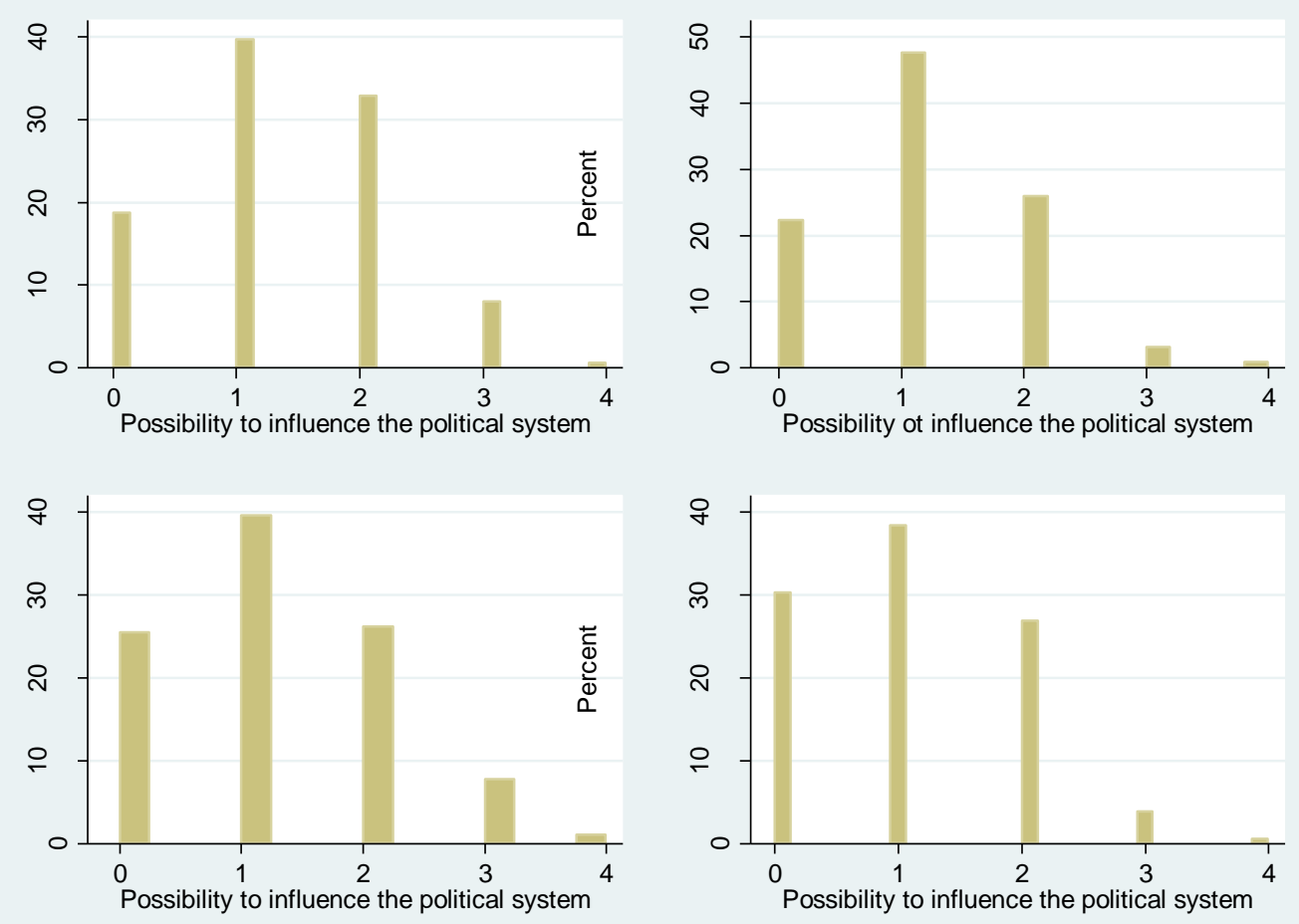